NBER WORKING PAPER SERIES

\title{
INFORMAL FINANCIAL NETWORKS: THEORY AND EVIDENCE
}

\author{
Mark J. Garmaise \\ Tobias J. Moskowitz \\ Working Paper 8874 \\ http://www.nber.org/papers/w8874
NATIONAL BUREAU OF ECONOMIC RESEARCH
1050 Massachusetts Avenue
Cambridge, MA 02138
April 2002

\begin{abstract}
We thank the Center for Research in Security Prices and the Dimensional Fund Advisors Research Fund for financial support. Special thanks to Michael Arabe, John Edkins, and Peggy McNamara as well as COMPS.com for providing the U.S. real estate data, and to Bob Figlio, Dave Ingeneri, and CAP Index, Inc. for providing the crime data. We are grateful to Stephen Cauley for his assistance and advice and we have benefitted from suggestions and comments from David Barker, Doug Diamond, Eugene, Fama, Joe Gyourko, Gordon Phillips, Matthew Spiegel, two anonymous referees, the editor, Maureen O'Hara, and seminar participants at the University of Illinois, the University of Maryland, the University of Chicago, Wharton, UCLA, the NBER Summer Institute on Asset Markets and Real Estate, and especially Raghu Rajan. The views expressed herein are those of the authors and not necessarily those of the National Bureau of Economic Research.
\end{abstract}

(C) 2002 by Mark J. Garmaise and Tobias J. Moskowitz. All rights reserved. Short sections of text, not to exceed two paragraphs, may be quoted without explicit permission provided that full credit, including (C) notice, is given to the source. 
Informal Financial Networks: Theory and Evidence

Mark J. Garmaise and Tobias J. Moskowitz

NBER Working Paper No. 8874

April 2002

JEL No. G2, G3

\begin{abstract}
We develop a model of informal financial networks and present corroborating evidence by studying the role of professional property brokers in the U.S. commercial real estate market. Our model demonstrates how service intermediaries, who do not supply finance themselves, can facilitate their clients' access to finance via repeated informal relationships with lenders. Empirically, we find that, controlling for endogenous broker selection, hiring a broker strikingly increases the probability of obtaining a bank loan from 40 to 58 percent. Our results demonstrate that even in the U.S., with its well-developed capital markets, informal networks play an important role in controlling access to finance.
\end{abstract}

Mark J. Garmaise

Graduate School of Business

University of Chicago

1101 E. 58th St.

Chicago, IL 60637

mark.garmaise@gsb.uchicago.edu
Tobias J. Moskowitz

Graduate School of Business

University of Chicago

1101 E. 58th St.

Chicago, IL 60637

and NBER

tobias.moskowitz@gsb.uchicago.edu 


\section{Introduction}

Research on financial intermediation forms a central part of the theoretical literature in corporate finance. Most of this research focuses on the role of formal financial intermediaries such as commercial banks (Diamond (1984)). Yet, in many economic settings, informal financial networks fulfill a critical function in determining access to credit. In the small and medium business finance market, lawyers, accountants, insurance agents, consultants, suppliers, customers, and brokers often act as informal financial intermediaries. ${ }^{1}$ In developing countries informal networks of middlemen perform a vital role in the allocation of capital.

Informal intermediaries are not themselves a source of finance, but connect borrowers and lenders while providing other commercial services. Despite their pervasiveness and importance, there is little theoretical modeling of their function. It is also difficult to empirically document the nature and significance of informal financial networks. We provide a theoretical model of informal financial networks and analyze the implications of this model for a unique data set detailing brokerage activity in the U.S. commercial real estate market. Our empirical evidence is striking in that it demonstrates the importance of informal financial networks, even in the U.S., a country with very well-developed capital markets.

Informal financial networks consist of borrowers, lenders, and intermediaries who do not supply finance themselves but who facilitate financing transactions by virtue of their relationships with both borrowers and lenders. In developing countries, the role of informal financial intermediary may be played by traders (Burkett (1988) and Cobham and Subramaniam (1998)). Informal networks are also important in the venture capital market (Mason and Harrison (1997)). These intermediaries fulfill a crucial function in markets in which borrowers seek financing relatively infrequently and have little opportunity to develop relationships with lenders themselves. Informal intermediaries can establish relationships with both lenders and borrowers to make cooperation between the two parties feasible. Borrowers who can benefit from this form of cooperation include entrepreneurs seeking business loans, individuals in need of home mortgages, farmers looking for farm loans, and small corporations who require bank financing. The set of loan seekers who profit from the aid of informal intermediaries is very wide.

We present a model of a general informal financial network that demonstrates that non-financial

\footnotetext{
${ }^{1}$ See, for example, Business Week, March 2, 1998, p.6 ENT.
} 
intermediaries who participate in a market over the long-run can facilitate their clients' access to loans. The central hypotheses tested in this paper arise from our theory of cooperation between non-financial (or service) intermediaries and lenders. In the course of repeated interactions, service intermediaries and lenders may develop a relationship. A lender may agree to grant preferential access to finance to a service intermediary's clients in exchange for the service intermediary directing loan-seekers to it. In our model, lenders cooperate with service intermediaries by expending effort to expedite the evaluation of loan applications made by the service intermediary's clients. This allows more transactions to be consummated, generating more fees for the service intermediary. In return, the service intermediary advises all his clients to seek a loan from the lender. Borrowers without service intermediaries participate in the market only infrequently and cannot therefore promise future business to a lender. Lenders are thus unwilling to expedite the loan requests of borrowers when no service intermediary is present. Informal networks of service intermediaries and lenders develop as both parties build reputational capital and agree to cooperate.

To test the implications of our theory, we apply the model to the commercial real estate market. Here, the service intermediary is a property broker, and the lender with whom he builds a relationship is a bank. The commercial real estate brokerage market is a particularly appropriate subject for our empirical study for several reasons. First, broker intermediation is an especially important form of informal financial intermediation. Our study shows that brokers serve a central role in providing their clients with access to finance. Second, the commercial real estate market is a large and important asset market. ${ }^{2}$ It is therefore of significant economic interest to have theories that explain the role of intermediaries in commercial real estate. Finally, the commercial, as opposed to the residential, real estate brokerage industry has received very little attention in the literature (Yang, Trefzger, and Sherman (1997)), despite its size and importance.

In our empirical study, we find strong evidence that brokers form informal relationships with banks, directing business to banks in exchange for preferential access to finance for their clients. Our central empirical findings are as follows. First, hiring a broker raises the probability that a transaction will be financed with bank debt from 40 to a striking 58 percent. Second, brokers tend to concentrate their deals among a small set of banks, and brokers whose business is most concentrated among a few banks (i.e., those with the closest ties to a specific set of banks) have the

\footnotetext{
${ }^{2}$ The value of outstanding commercial mortgages alone in the U.S. in 1999 was in excess of $\$ 1.3$ trillion (Werner, 2000), and this figure does not include the value of commercial real estate equity.
} 
strongest positive influence on their clients' access to finance. Third, brokers and banks in longer relationships grant each other a larger share of their respective businesses. Fourth, brokers with longer histories have a particularly strong effect in increasing the probability of a bank loan for their clients. Finally, brokers who exhibit more loyalty (in terms of consistently directing clients) to the bank improve access to finance for their clients by an even greater margin, while disloyal brokers actually decrease the likelihood of obtaining subsequent finance for their clients. These results are obtained by instrumenting brokerage activity and therefore do not depend on endogenous broker selection. These findings strongly suggest that brokers and banks develop informal relationships, and that informal broker-bank networks have a significant effect in determining the availability of finance.

We also consider three alternate theories of brokerage intermediation that predict an association between broker presence and the frequency of bank finance. The first alternate theory is that brokers monitor banks and acquire useful information about the ability and propensity of different banks to make loans. They then direct their clients to the bank that is likeliest to grant a loan. The second alternate theory is that broker certification of properties, and possibly borrowers, encourages banks to make loans in brokered transactions. This is similar to the certification role played by commercial and investment banks (Puri (1994,1996)) and venture capitalists (Brav and Gompers (1997)). The third alternate theory is that sellers who use brokers may do so because they are liquidity-constrained and in need of a quick sale. Such sellers are unlikely to provide seller finance, so buyers in brokered deals may be forced to seek bank finance more aggressively. The evidence for the alternative theories is rather weak and uncompelling.

Our data contain 36,678 commercial real estate transactions from across the U.S. over the period January 1, 1992 to March 30, 1999. Our sample includes detailed financing information as well as a large set of buyer, seller, broker, and property attributes. Sale price, income and expenses, and property type are also reported. The large size of our data set affords us substantial power, and the extent of property financing and property characteristic information allows for a detailed examination of this market. We employ the robust semiparametric estimators of Powell (1986) and Klein and Spady (1993). The estimates generated by these techniques are regarded as conservative and reliable.

Finally, by demonstrating the important role played by brokers in providing access to finance, we have identified a broker service not previously recognized in the literature. Previous research 
has stressed two main broker functions: reducing property time on the market (e.g., Knoll (1988), Yang and Yavas (1995), and Williams (1998)) and increasing the realized sale price (e.g., Jud and Frew (1986) and Janssen and Jobson (1980)). Our data does not permit us to analyze the former, but we provide evidence on the latter. We find that hiring a list broker increases the realized sale price only negligibly (consistent with Zumpano, Elder, and Baryla (1996)). We display evidence, however, that brokers significantly improve access to finance. The broker offers a bundle of services including marketing assistance and financial access. For some sellers (e.g., impatient sellers with high discount factors) the value of these services exceeds the brokerage fee and they engage the broker. Other sellers elect not to pay for a broker. Our theoretical and empirical results on brokers' informal financial intermediation suggests a new and important brokerage function that has not been well-studied in the literature.

Our results demonstrate the crucial role played by networks of property brokers and banks in determining financing in the U.S. commercial real estate market. Despite the existence of a welldeveloped bank lending system, brokers with no formal contractual authority perform a critical task in arranging financing. The decentralized and essentially local character of broker networks parallels that of informal financial systems in developing markets. Frequent interactions and the resulting development of reputational capital are at the core of these informal lending channels (Ville and Fleming (2000)). Similar informal communication arrangements are also important in the venture capital market (Mason and Harrison (1997)), and have historically played a broad role in the financing of small businesses (Godley and Ross (1996)). This study provides some evidence on the benefits enjoyed by those with access to informal networks.

The rest of the paper is organized as follows. Section II describes a theory of informal financial intermediation based on cooperative relationships between non-financial intermediaries and lending institutions. Section III details our data set used to examine informal lending channels in the commercial real estate market, highlighting the various forms of financing observed in this market and describing the characteristics of properties and market participants. This section also describes the econometric methodology employed in the paper. Section IV addresses the endogenous selection of brokers and identifies several instruments for brokerage activity. These are employed in our analysis of broker influence on financial structure. Section V conducts our empirical tests for broker-bank relationships and their influence on financial structure and Section VI tests alternative theories of broker involvement and financial influence. Finally, Section VII concludes. 


\section{Theory of Informal Financial Networks}

We develop a theory of informal financial cooperation in a lending game. We consider four agents in this market: buyers who need to borrow funds, sellers, service intermediaries, and lenders. We presume all participants are involved in a repeated game with both long-run and short-run players. Lenders and long-run service intermediaries are long-run players who play every period in an infinitely repeated game. Sellers, buyers, and short-run service intermediaries are shortrun players who each play only one period. There are $i>1$ lenders and $j>1$ long-run service intermediaries. The number of buyers and sellers is equal in every period $t$ and is denoted by $p_{t}$, which may vary from period to period. The number of short-run service intermediaries in period $t$ is given by $s s_{t}$, which may also be time-varying. All players are risk-neutral and discount the future using the discount factor $\delta \in(0,1)$.

This simple game may be thought of as representing many different types of economic activities. For instance, in applying the game to the small business finance market, the buyer would be an entrepreneur seeking some initial capital to establish his firm, lawyers or accountants would act as service intermediaries and lenders would be banks, large financial institutions, or private outside equity sources such as angels. In other corporate settings, the buyer would be a firm seeking to purchase an asset, the lender would be a commercial bank and the role of service intermediary may be played by a large customer or supplier of the buyer. Alternatively, this model could apply to a developing country in which the buyer is a small producer or farmer seeking to upgrade his physical capital. Private money lenders, rich individuals, and banks act as lenders and produce traders or goods-conveying middlemen act as service intermediaries. In addition, the model can be used to describe real estate markets in which buyers may be firms or partnerships purchasing a commercial property or individuals purchasing a home, banks and insurance companies provide finance, and commercial or residential brokers function as service intermediaries. In the empirical section, we will use our data set on commercial property transactions and brokerage activity to test some of the implications of the theory we develop below. The model, however, extends beyond this market and may be applied to a number of settings.

In each period, the number of short-run service intermediaries $s s_{t}$ is generated by an exogenous

random process. Each service intermediary $s$, both long-run and short-run, generates $l_{s} \geq 1$ 
potential transactions each period, and each transaction involves a buyer and seller. For simplicity we will assume that there is only one service intermediary involved in every potential transaction. There are also $l_{u s}$ potential transactions that do not involve a service intermediary. Potential transactions are of either good or bad quality. The present value of the asset to the seller is $n>0$. A good buyer possesses a short duration opportunity to increase the value of the seller's asset to $\frac{v+n}{\delta}$ next period. A bad buyer will extract the value $n$ from the asset for his personal benefit and leave the asset with a value of 0 . Buyers know whether they are good or poor, but initially no one else is privy to this information. A proportion $p \in(0,1)$ of potential buyers are good. The precise allocation of bargaining power between the buyer and the seller is unimportant for our results. For simplicity we will assume that in all cases sellers play a completely passive role and that the buyer and seller agree to transfer the asset at a price $n$.

The consummation of these agreements between buyers and sellers requires that the wealthconstrained buyers receive financing in the amount of $I \in(0, n)$, since buyers hold only $n-I>0$ in cash. This financing may be obtained from a lender. All lenders are presumed to be individually capable of financing all projects. Since opportunities are of short durations, buyers only have time to seek a loan from one lender. In transactions involving a service intermediary, buyers will seek advice from their service intermediaries about which lender to approach. If the lender does not provide financing, the buyer may liquidate some of his long-term assets inefficiently to provide the required financing. This inefficient liquidation has a cost $c$ to the buyer.

The lenders evaluate all loan applications received in one of two ways. A standard evaluation will distinguish good buyers from bad ones, but requires so much time that only $\frac{q}{p} \in(0,1)$ of all good transactions can be completed since some opportunities will disappear due to the passing of time. To conduct a standard evaluation, the lender must exert an unverifiable effort cost $e_{0}<\frac{q v}{2}$. An expedited evaluation also distinguishes good and bad buyers, but does so quickly enough that all good opportunities may be exploited. An expedited evaluation requires an observable but unverifiable effort with cost $e_{1} \in\left(e_{0}, \frac{p v}{2}\right)$ on the part of the lender. ${ }^{3}$ It is not known in advance to any player whether an expedited evaluation will be required for any particular potential transaction. If the buyer is determined to be good by the lender and the opportunity is still available, the buyer

\footnotetext{
${ }^{3} \mathrm{~A}$ very similar model would allow the bank to exert additional effort in the evaluation process if it wished to ensure that the credit quality of marginal types is always determined and not left ambiguous.
} 
and the lender bargain over the interest rate on the loan. In the bargaining game, the lender and the buyer both simultaneously propose a repayment next period for the loan of $I$ today. If the proposed amounts are identical, then the loan is provided on the agreed terms. If the lender and buyer disagree, the loan is not provided. In the absence of lender financing, a buyer may elect to self-finance, which incurs an inefficient liquidation cost $c$ that is distributed uniformly on the range $[v-\epsilon, v+\epsilon]$ (independently across service intermediaries), for $0<\epsilon<\frac{v}{2}$. If the transaction is consummated, the service intermediary receives a fixed fee $0<f<\frac{v}{2}$.

The timing of the stage game is as follows:

1. The number of short-run service intermediaries and the number of potential transactions are exogenously determined.

2. Service intermediaries, when engaged, advise the buyer to apply to a specific lender.

3. Each buyer applies for a loan from one lender.

4. Lenders decide whether to evaluate each loan in a standard or expedited manner. Evaluations are then conducted.

5. Loans are approved or rejected and buyers and lenders bargain over the terms of approved loans. Rejected buyers choose whether or not to self-finance. Service intermediaries receive their fees in completed transactions.

6. In the following period, the asset achieves its new value and the lender loan is paid off from the value of the asset.

We make the following parametric assumptions. The lender will not approve loans without evaluating them:

$$
p(v+s)+(1-p)(0)<I .
$$

Expedited evaluation is ex-ante efficient:

$$
(p-q) v>e_{1}-e_{0}
$$

Expedited evaluation is not in the lender's short-term interest:

$$
\frac{(p-q) v}{2}<e_{1}-e_{0}
$$


We also presume that loan application and transaction information is private and is only available to buyers, sellers, service intermediaries, and lenders who participate in the particular transaction.

In our first result, we show that if the discount factor is sufficiently high, then cooperative dyadic relationships between lenders and long-run service intermediaries can emerge.

Result 1: For sufficiently high $\delta<1$, there is a subgame perfect equilibrium of the lending game in which

1. A set of $i_{c}>0$ cooperative long-run service intermediaries follow a strategy of advising all their clients to request loans from one specific lender, where this lender may differ across service intermediaries, as long as the service intermediary has done so in every previous period and the lender has expedited all the loan requests ever made by its clients. Otherwise, the service intermediary follows a mixed strategy of recommending that his clients seek loans from every other (non-dyadic) lender with equal probability. A cooperative long-run service intermediary is said to be in a dyadic relationship with the given lender to which it directs all its customers. All short-run service intermediaries and $i_{n c}=i-i_{c}>0$ non-cooperative long-run service intermediaries play a mixed strategy of advising their buyers to seek a loan from each lender with equal probability.

2. All buyers follow the advice of their service intermediaries, and buyers in deals without a service intermediary follow a mixed strategy of applying for a loan from each lender with equal probability.

3. A lender in a dyadic relationship with a cooperative long-run service intermediary expedites all the loan requests made by the clients of this service intermediary, and approves all loan requests from good buyers, as long as at least one client of the service intermediary has approached the lender in each period. If in any period none of the service intermediary's clients has requested a loan, or if the lender has ever evaluated one of the service intermediary's client's loan applications in the standard manner, then in all subsequent periods the lender evaluates all the service intermediary's clients' loan requests in the standard manner and approves all loans requested by good buyers. All loan requests recommended by a cooperative service intermediary not in a dyadic relationship with the lender, a non-cooperative long-run service intermediary, or a short-run service intermediary or made by a buyer himself without a service intermediary, are evaluated in the standard manner and approved if the buyer is good. 
4. The outcome of the bargaining game between a lender and a good buyer is that the lender grants a loan in the amount of I that has a promised repayment in the next period of $\frac{I+\frac{v}{2}}{\delta}$. Good buyers who were turned down for a loan self-finance if $c \leq v$ if they have no service intermediary and if $c \leq v-f$ if they have a service intermediary.

A proof is given in Appendix A.

In our second result, we show that lenders will not cooperate with any short-run player.

Result 2: For no value of $\delta$ is there a Nash equilibrium of the lending game in which a lender provides an expedited evaluation of the application of a buyer without a service intermediary or of the application of a client of a short-run service intermediary.

A proof is given in Appendix A.

The equilibrium described in Result 1 is robust to changes in the structure of the lending game that make more information public. The strategies described constitute an equilibrium in games in which transactions data is made available to all long-run players or, indeed, all players. The intuition underlying Result 2 that cooperation between lenders and short-run players is unlikely to emerge also holds under varying information structures, as long as some information such as the number of loan applications received by a lender remains private. In almost all settings this is likely to hold. For example, consider a model in which all historical transactions data is available to all players, but the number of loan applications received by a lender is private. If the variation in the number of applications is sufficiently large, then the information content of the public transactions data will be inadequate to sustain cooperation between lenders and short-run players (Kandori (1992)). Equilibria in which lenders and long-run service intermediaries cooperate will, however, continue to exist.

This model focuses on the service intermediary's role in aiding his clients in securing loans, but service intermediaries also perform other services such as marketing assistance, consulting, legal advice, etc., and it is often these other services which the client is primarily interested in obtaining. For some buyers (e.g., impatient buyers with low discount factors) the value of these services exceeds the service intermediation fee and they engage the service intermediary. Other buyers elect not to pay for a service intermediary. The indirect form described of the cooperation, in which lenders reward service intermediaries for business by expediting their clients' loan applications rather than through direct payments, skirts the moral hazard issues and legal restrictions associated with such 
payments. ${ }^{4}$ As a result of these concerns, service intermediary-lender relationships are usually informal, though some service intermediaries and lenders have established formal joint ventures (Stahl (1993)).

\section{A. An Application to Commercial Real Estate}

We will now develop implications from the theory for our commercial real estate data in order to test its implications. Here, we can view the service intermediaries as brokers and the lenders as banks. We will presume that Result 1 describes the equilibrium. Good buyers who do not use brokers receive bank loans with probability $\frac{q}{p}$. Those who do not receive bank loans self-finance with probability $\frac{1}{2}$. This implies that of non-brokered completed transactions, a fraction $\frac{2 q}{q+p}$ receive bank financing. Since banks expedite the loan applications of the clients of cooperative long-run brokers, all completed transactions of these buyers receive bank loans. The good clients of brokers who do not cooperate with a bank (whether short-run or long-run), receive bank financing with probability $\frac{q}{p}$. Those who do not receive bank loans self-finance with probability $\frac{\max \{\epsilon-f, 0\}}{2 \epsilon}$, which implies that $\frac{2 q \epsilon}{q(2 \epsilon-\max \{\epsilon-f, 0\})+p(\max \{\epsilon-f, 0\})}$ of the completed transactions of these buyers receive bank finance. The inequalities

$$
1 \geq \frac{2 q \epsilon}{q(2 \epsilon-\max \{\epsilon-f, 0\})+p(\max \{\epsilon-f, 0\})}>\frac{2 q}{q+p}
$$

provide us with our first prediction.

Prediction 1. Brokered deals are more likely to receive new bank financing.

The clients of brokers in cooperative relationships with banks receive expedited evaluations of their loans which leads to more approvals. Clients of brokers who do not have cooperative relationships do not enjoy preferential access to loans, but they are less willing to self-finance than buyers in non-brokered transactions, since they must pay a broker's commission in addition to

\footnotetext{
${ }^{4}$ Service intermediaries who receive referral fees from lenders might be inclined to direct their clients to the lenders with the highest fees, rather than the best loan terms. As a result, clients would disregard the advice of their service intermediaries. In the cooperation model presented in this section, clients share in the benefit given by the lender (higher loan acceptance rates), and will therefore accept their service intermediary's recommendation. From a legal perspective, formal relations between lenders and certain service intermediaries are often prohibited. For example, in the real estate market lenders and brokers are governed by the ambiguous Real Estate Settlement Procedures Act (RESPA) of 1974. RESPA was interpreted to prohibit lenders from paying fees to service intermediaries in exchange for commercial loan business. Certain formal partnerships between brokers and lenders were permitted. Regulatory changes enacted in 1994 by the Department of Housing and Urban Development explicitly exempted commercial loans from the RESPA provisions (ABA Bank Compliance 16.3, March 1995).
} 
engaging in costly self-financing. As a result, buyers with non-cooperating brokers are also more likely to use bank finance in completed transactions than buyers without brokers.

In the equilibrium described in Result 1, cooperating brokers send all their clients to one specific bank. Cooperation is sustained by repeated interaction between the broker and the bank. The bank is able to verify each period that the broker is sending it at least one buyer. In more general settings, brokers may cooperate with a few banks, but relationships can only be maintained with a small number of banks.

Prediction 2. Brokers will concentrate their deals among a small number of banks.

In the equilibrium in Result 1, there are both cooperating and non-cooperating brokers. Only cooperating brokers increase their clients' probability of receiving a bank loan. Cooperating brokers will have a long history of dealing with one bank.

Prediction 3. Brokers with strong bank relationships will have a larger effect on the granting of bank loans than the average broker.

Cooperating banks will have relationships with specific banks. In the equilibrium of Result 1 , cooperating brokers send all their clients to one bank. Non-cooperating brokers, both short-run and long-run, send their clients to all banks with equal probability. Brokers who have dealt with a bank for multiple periods are likely to be cooperating banks who will send all their clients to the same bank in the future, as well. The empirical analog for this is that brokers and banks with long relationships should be expected to do more business with each other than with agents with whom they have short relationships.

Prediction 4. Brokers will direct a greater proportion of their clients to banks with whom they have longer relationships.

Banks expedite the loan evaluation process for the clients of cooperating brokers with whom they have long relationships. This results in more loan approvals for these buyers. Banks do not perform this service for the clients of brokers with whom they have a short-term relationship.

Prediction 5. Banks will offer more loans to the clients of brokers with whom they have longer relationships. 
In the equilibrium described above, short-run brokers do not develop cooperative relationships with banks. Result 2 shows that it is very hard for such cooperation to arise in equilibrium. Only long-run brokers cooperate with banks and raise their clients' loan approval rates.

Prediction 6. Brokers who have participated in the market for a longer period of time will have a larger effect on the granting of bank loans than the average broker.

Buyers seeking financing may also approach a second source of loans, the seller of the property. Sellers are less diversified than banks, and loans by sellers are inefficient from a diversification standpoint. Such loans must offer unattractive terms to compensate sellers for the idiosyncratic risk that they bear. As a result, such loans, known as vendor-to-buyer (VTB) loans, are less attractive to buyers but may be used to complete transactions. ${ }^{5}$

We may incorporate VTB loans into the model by assuming that some sellers are liquidity constrained and apply a discount factor $\beta<\delta$ to next period's cash flows. If the buyer has been rejected by a bank, he may seek seller financing. The seller cannot evaluate the buyer and has a low discount factor and will therefore demand a high interest rate, but for $I$ sufficiently low (i.e., when the buyer provides most of the sales price in cash) and for $\frac{p-q}{1-q}$ sufficiently large (i.e., many good buyers are rejected by banks), there are equilibria in which the seller provides finance. A buyer who has a broker is likelier to have been rejected by the bank because he is a bad type. A seller will be willing to offer less finance to such a buyer. That is, only for smaller values of $I$ will sellers finance buyers with brokers in equilibrium.

Prediction 7. When the buyer does not receive bank financing, the size of VTB loans will be smaller in brokered deals than in non-brokered deals.

Finally, since banks must typically approve the assumption of an existing mortgage on a property by a new buyer, broker-bank relationships should also encourage banks to permit the assumption of old mortgages. This will only apply if the broker happens to have a relationship with the bank holding the previous mortgage on the property. It may be the case, however, that the seller will

\footnotetext{
${ }^{5}$ In private conversations, brokers explained that VTB finance was typically only proffered if the buyer could not secure bank finance. Nothaft and Westfall (1985) argue that seller finance in the residential real estate market is often used by buyers only until they find bank finance on better terms than those available when the transaction was completed. Zinn (1991-1992) and Wilder (1995) indicate that seller finance is used as financing of last resort in commercial real estate. Garmaise and Moskowitz (2001a) provide evidence that seller financing is not used to reduce information asymmetries.
} 
choose his broker with this criterion in mind, or that the seller will receive a broker recommendation from his bank. In both these cases, a broker-bank relationship is possible and will improve the probability that loan assumption will be permitted, in analogy with the model of new bank loans given earlier.

Prediction 8. Brokered deals are more likely to receive assumed mortgage financing.

\section{Data and Methodology}

\section{A. The U.S. Commercial Real Estate Market}

Our sample consists of commercial real estate transactions drawn from across the U.S. over the period January 1, 1992 to March 30, 1999 from COMPS.com, a leading provider of commercial real estate sales data. ${ }^{6}$ Of the 36,678 commercial real estate transactions reported over our sample period, 22,642 met our initial data requirements (i.e., recorded sale price, financing data, identities of principals, property location, and information on broker activity). The data span 11 states: California, Nevada, Oregon, Massachusetts, Maryland, Virginia, Texas, Georgia, New York, Illinois, and Colorado, as well as the District of Columbia. COMPS attempts to comprehensively capture property sales across all regions within the states, rather than focus exclusively on the largest metropolitan areas. Defining the "city center" as the largest city or cities in each state, ${ }^{7}$ Table I reports that fewer than half of all transactions occur in city centers. Various property types are also covered by COMPS. We group properties into three mutually exclusive types: apartments (defined as multi-family dwellings, apartment complexes, condominiums, and townhouses), vacant land, and commercial and industrial buildings, comprising about 35 percent, 18 percent, and 47 percent of property sales, respectively.

\section{A.1 Property Characteristics}

Table I reports summary statistics on the U.S. commercial real estate market. Panel A contains general information about the properties. The mean age of all properties is 35.5 years, with older

\footnotetext{
${ }^{6}$ COMPS collects data on commercial real estate transactions by contacting buyers, sellers, and brokers, and then confirms their reports with each of these parties. The COMPS data are considered very accurate in the industry, and provide information on sale prices, income and expenses, financing data, property types, and buyer, seller, and broker details.

${ }^{7}$ The city centers for each state are defined as follows: CA-Los Angeles and San Francisco; NV-Las Vegas; ORPortland; MA-Boston; MD-Baltimore and DC area; VA-DC area; TX-Austin and Dallas; GA-Atlanta; NY-New York city; IL-Chicago; CO-Denver. San Diego, CA and Houston, TX were not covered by COMPS over the sample period.
} 
properties residing in cities (42.5 years) and younger properties located outside of major cities (29 years). We further identify properties with imminent planned development by assuming that purchasing development firms plan to develop the property in the immediate future. In addition, we presume that properties that are zoned "PUD" (planned unit development) ${ }^{8}$ are scheduled for immediate development. Approximately 6.3 percent of property sales are scheduled for development, with a much higher fraction (16.3 percent) for vacant land deals. More development occurs outside of major cities and among larger deals. Panel A also reports the capitalization rate (cap rate) on the properties, which is defined as net operating income divided by the sale price. The average property earns 9.35 cents in income per dollar of value. This ratio is slightly higher for apartments.

COMPS also provides eight digit latitude and longitude coordinates of the property's location. From these, we construct characteristics of the local market in which each property resides. For instance, a crime score index for each property location is provided using crime data from CAP Index, Inc. Eight digit latitude and longitude coordinates are precise to within 10 meters, and CAP Index, Inc. provides crime rate data for this level of refinement. Thus, we obtain a property specific crime score, where properties on the same city block can and often do have different crime scores. ${ }^{9}$ The crime scores measure the probability that a certain crime will be committed in a given location relative to national and local (county) levels of crime. For example, a local crime score of 1 means that the likelihood of a particular crime being committed is the same in the location as the county average. Crime scores range from 0.1 to 20. CAP Index, Inc. scores the seven crimes listed in the FBI's Uniform Crime Reports (UCR) as Part 1 Offenses. These are homicide, rape, robbery, aggravated assault, burglary, larceny, and motor vehicle theft. These crimes are classified into two categories: Crimes against persons (homicide, rape, robbery, aggravated assault), and crimes against property (burglary, larceny, motor vehicle theft). ${ }^{10}$ For brevity, and due to the high correlation among the various personal crime measures as well as among the various property crime measures, we employ the homicide rate as our measure of personal crime risk and the larceny rate

\footnotetext{
${ }^{8}$ Planned unit development is a zoning designation for property which waives standard zoning requirements and permits the adoption of a set of site-specific development standards.

${ }^{9} \mathrm{CAP}$ Index, Inc. computes the crime score index for a particular location by combining geographic, population, economic, and education data with local police, victim, and loss reports. The demographic data on population, income, and education levels are derived from the Census Bureau, which reports these statistics for each of over 100,000 census tracts in the U.S. The census tracts typically cover several square block areas within cities and slightly larger areas in more remote locations. For example, Cook County Illinois contains 1,352 census tracts.

${ }^{10}$ For more details on the construction and composition of the CAP Index, Inc. crime database, see Garmaise and Moskowitz (2000b).
} 
for property crime risk. We will use the former as an instrument for broker presence, and the latter as a control. The correlation between these two crime scores is less than 0.50 , and results in the paper are robust to several other crime score measures. Panel A of Table I indicates that the properties in our sample are almost twice as likely to be the scene of a crime than the county average. Not surprisingly, properties in major cities have higher crime levels, and vacant land is subject to slightly lower crime rates.

\section{A.2 Market Participants}

Another interesting aspect of our data set is the detailed information provided about market participants. COMPS provides the location (city and state) of the buyer and seller, which we match with latitude and longitude coordinates provided by the Geographic Names Digital Gazetteer, published by the U.S. Geological Survey. Using the latitude and longitude coordinates of each market participant and the property, we compute the actual distance (in kilometers) between these two locations using the arclength formula in Coval and Moskowitz (1999). Panel B attests to the highly localized nature of the commercial real estate market, as noted in Garmaise and Moskowitz (2000a).

More importantly, our data contain information on the use of professional brokers (service intermediaries) in the deals. In many cases, the seller hires a broker to list and market the property. It is also common for a second broker, the sale broker, to participate in the transaction by hearing about the listing and finding a potential buyer. In some cases both functions are performed by the same broker. Upon sale of the property, the seller pays the commission to both brokers (typically split evenly between them). In any case, brokers are uniformly interested in completing the transaction (and hence receiving their commission) and therefore may be interested in obtaining finance for their clients in order to do so. We will use their participation in this market to test our more general theory of informal financial networks.

Brokers participate in more than 65 percent of property sales in our database. As Table I Panel B indicates, the use of brokers is far more common for the sale of apartment complexes and far less common for vacant land deals. Finally, in a small number of cases the broker acts as a principal rather than an agent, buying (3.2 percent of the time) or selling (2.7 percent of the time) the property on his own account. In these cases, the broker is not acting as a service intermediary and, therefore, we must control for these few occurrences in our empirical analysis. It is clear from Table I that broker involvement is pervasive in the commercial real estate market. We examine 
their economic role, focusing particularly on their influence on client financial access.

\section{A.3 Financial Structure}

We wish to understand financing patterns in the commercial real estate market, and how they are related to brokerage activity. Our data set contains detailed financing information for each property transaction. Four types of financing appear in the data. Buyers either use cash, receive financing from the seller (known as vendor-to-buyer (VTB) financing), assume an existing mortgage on the property, or obtain a new mortgage from a bank. In many cases, some combination of these financing types is used. While generally little equity financing is used in real estate transactions, COMPS does not track the presence of equity and essentially treats it as cash. Our tests primarily focus on the three other types of financing and the choice between seller and bank financing. Bank financing is generally cheaper than VTB loans due to the illiquidity and lack of diversification of sellers. VTB financing is often subordinate to bank debt and is generally the residual loan used to complete the deal.

Panel C of Table I contains information about property financing. The average sale price of the properties is just under $\$ 2.4$ million, ranging from $\$ 20,000$ to $\$ 734$ million over the sample period, with a median sale price of $\$ 618,000$. Approximately 5 percent of buyers assume an existing mortgage on the property, which typically comprises 67 percent of the purchase price when present. More than 52 percent of buyers obtain a new mortgage, comprising 73 percent of the price when this form of financing is used. Perhaps one of the most interesting features of the commercial real estate market is the extent of VTB financing. VTB financing is used in nearly 19 percent of cases, and comprises almost 60 percent of the purchase price when used. VTB loans, while typically junior to bank loans, are not short-term "bridge" financing used to expedite the deal. The maturity of VTB loans is often as long as (or longer than) the maturity of bank loans.

In this paper, we examine both the frequency and magnitude of each form of financing, and are careful to distinguish between these two features of the data. Our theory makes distinct predictions about the probability of a financial instrument being used, but not necessarily the size of the loan contract. We will show how brokerage activity affects these two aspects of financial structure. Summing all of the debt on each property as a fraction of its sale price, the average loan to value ratio is 72.6 percent across all properties (value-weighted), with only marginal differences across property types. Therefore, the most significant variation exhibited across property types is in 
the type of debt contract used. In this respect, vendor and bank financing may be considered substitutes.

\section{B. Econometric Methodology}

Because of the unique nature of our financing variables and recent econometric developments, we run robust semiparametric regression models in our analysis that overcome some of the problems noted in parametric estimators. The financing variables that serve as dependent variables in our regression models are nonnegative; buyers do not, for example, take out mortgages in a negative amount. In addition, some of our financing variables, such as seller financing, occur less than 20 percent of the time. These features of the data must be taken into account in our econometric analysis. Ordinary least squares is inappropriate for data censored in this way and adjusted estimators must be used. We analyze the form of financing using both the Klein and Spady (1993) binary response model and the truncated regression model of Powell (1986). The appendix details these two regression specifications. ${ }^{11}$ These two forms of analysis describe two distinct aspects of the data. The binary response model provides information on the factors determining the frequency of various forms of financing, while the truncated regression indicates which variables increase the magnitude of the types of financing when they are present. The descriptive statistics in Table I demonstrate that our variables of interest often have a different impact on the frequency and magnitude of a given form of financing. We therefore do not conduct censored regressions (such as Tobit or Powell's (1984) Censored Least Absolute Deviation (CLAD) model) in this paper because they combine both types of information into a single model, obscuring this important distinction.

In addition to these robust estimators, for both the binary response and truncated regressions, we employ the methodology of Fama and MacBeth (1973) to compute robust standard errors on our coefficient estimates. Specifically, we run the regressions for each year separately and report the time-series average of the coefficient estimates along with their associated time-series t-statistics. The Fama-MacBeth methodology accounts for potential cross-correlations in the residuals by running regressions separately for each year. This procedure is the same as running a panel (pooled

\footnotetext{
${ }^{11}$ The binary response model of Klein and Spady (1993) is a robust semiparametric single index model that allows the error term to be unspecified. The truncated regression of Powell (1986) is a robust semiparametric estimator that is consistent and asymptotically normal under the assumption that the error terms, conditional on the regressors, are symmetrically distributed and unimodal. For further details about these robust regression models and their advantages, see the appendix, as well as Klein and Spady (1993), Powell (1986), and Garmaise and Moskowitz (2000a).
} 
time-series cross-section) regression that weights years equally and allows the constant, slope coefficients, and variable means to change across years. An advantage of the Fama-MacBeth procedure is that it does not require a constant panel of firms and the standard errors of the average slope coefficients allow for whatever drives the precision of these estimates. ${ }^{12}$

\section{Broker Activity and its Influence on Bank Financing}

\section{A. Instrumenting Brokerage Activity}

We begin by analyzing the conditions under which brokers are used. The goals of this analysis are twofold. First, in order to account for endogenous selection of brokers by certain types of buyers and sellers, we seek to identify exogenous predictors of brokerage activity that are otherwise unrelated to financial choice for use in instrumental variable regressions. Second, brokerage is an important aspect of the commercial real estate market, and it is useful to understand which buyer, seller, and property attributes are associated with the hiring of brokers.

We analyze the choice of hiring a broker by regressing the presence of brokers on property, buyer, and seller characteristics. The dependent variable is one if a broker is present in the deal (acting as an agent, not as a principal) and zero otherwise. The independent variables include a dummy variable indicating if the buyer is not a corporation, seller and buyer distance from the property, a dummy indicating whether the property is slated for immediate development, the property's age, dummies for property type (apartment and vacant land), a dummy for properties located in major cities (City-center), the crime rate score for crimes against property, and the log of the sale price. State dummies are also included as regressors, but their coefficient estimates are omitted from the table for brevity. The Klein and Spady (1993) binary response model requires setting one of the regression coefficients to a constant for scale normalization. We set the coefficient on $\log (\operatorname{Price})$ to 1 for scale normalization based on logit regression results that indicated a negative and statistically significant coefficient estimate on $\log$ (Price) (for further details on this model, see Klein and Spady (1993) and Garmaise and Moskowitz (2000a)).

In addition to the control variables, which may be related to both broker presence and financial choice, we employ five instruments for brokerage activity that we expect to be unrelated to financial

\footnotetext{
${ }^{12}$ For an example and discussion of the Fama-MacBeth methodology applied to a binary response model, see Fama and French (2000). In addition, they report that Fama-MacBeth standard errors are more than 2 to 5 times larger than those obtained from a pooled time-series cross-sectional panel regression that ignores residual cross-correlation.
} 
structure, except through their effect on broker presence. These instruments are added to the previously described regressors to predict the presence of a broker. The first instrument, Radius, measures the population density of the local area in which the property resides. The population density radius is defined as the minimum of the radius which encompasses 100,000 people and 3 miles (this data is obtained from Cap Index, Inc.). We expect more densely populated areas (i.e., those with low Radius measures) to have a higher likelihood of broker presence, since brokerage, which involves the physical showing of properties, is likely more cost-efficient in these regions. The second instrument is the personal crime score for the property's location. The risk of personal harm or death likely deters broker participation, since they must visit and display the property frequently. Controlling for the property crime rate as well as city-center location, the personal crime rate should not affect the form of financing (loan officers need not repeatedly visit the property). Since crime rates are also measured relative to the local county average, this instrument is really the orthogonal component of the murder rate once the property crime rate and local crime rates have been accounted for. The third instrument, $\sigma_{l o c a l}$, is the standard deviation of capitalization rates of all sales within a 10 mile radius of the property, excluding the property itself. This variable measures the cross-sectional price variance in the local market and indicates the extent of local property quality heterogeneity. Brokers specialize in marketing properties of a specific type and quality and can be expected to avoid districts with a wide diversity of varying properties. The $\sigma_{\text {local }}$ measure differs for each property and, because it excludes the property itself from the calculation, it is not mechanically related to the sale price. The fourth instrument is the dollar-weighted fraction of brokered deals within a 10 mile radius conducted by a national broker, excluding the property itself. ${ }^{13}$ This variable measures the degree to which brokers have penetrated the local market, since national brokers tend to dominate young, remote markets and only over time do smaller, regional brokers emerge. The smaller this fraction, the more developed the local brokerage networks and therefore the higher the likelihood of employing a broker. Finally, the last instrument we employ is the dollar-weighted Herfindahl index of brokerage activity within a 10 mile radius of the property

\footnotetext{
${ }^{13}$ The "national" brokers are the 12 largest national commercial real estate firms. These are Century 21, Coldwell Banker, Colliers International, Cushman and Wakefield Inc., The Galbreath Company, Grubb and Ellis Company, Koll Real Estate Group, Insignia/ESG, Marcus and Millichap Real Estate Investment Brokerage Company, REMAX, The Staubach Company, and Trammell Crow Company.
} 
(this measure also excludes the property itself). This index is defined for property $j$ as

$$
\begin{aligned}
\operatorname{Herf}_{j} & =\sum_{k \in K^{j}}\left(\frac{\$ B r o k_{j, k}}{\sum_{k \in K^{j}} \$ B r o k_{j, k}}\right)^{2}, \\
\$ B \text { rok }_{j, k} & =\sum_{i \in N^{(j, k)}} \$ P_{i}
\end{aligned}
$$

where $N^{(j, k)}$ is the set of properties within 10 miles of property $j$ (excluding the property itself) which were brokered by broker $k, \$ P_{i}$ is the sale price of property $i$, and $K^{j}$ is the set of distinct brokers who brokered a property within a 10 mile radius of property $j$. If a deal is brokered by two brokers, each is given one-half credit for the sale. The Herfindahl variable measures the competitiveness of the local brokerage industry. More competitive broker markets (i.e., those with lower Herfindahl measures), should have lower broker commissions and better broker services. Hence, broker hiring should be more prevalent in these markets.

Table II Panel A demonstrates that the instruments are successful in predicting brokerage activity. An F-test that the instruments should be excluded from the regression is clearly rejected (at less than the $0.5 \%$ level). Broker presence increases significantly when personal crime risk is low and when the local broker market is more competitive. Brokerage activity is negatively related to local property quality heterogeneity and is decreasing in the fraction of nationally brokered deals.

\section{B. Brokerage Activity and its Influence on Obtaining Bank Debt}

Using these instruments to generate exogenous variation in the presence of a broker, we examine whether broker presence influences the probability of obtaining a new bank loan or the size of the loan. Panel B reports the results from a regression of the frequency of bank financing on the instrumented measure of brokerage activity plus a set of control variables for property, buyer, and seller characteristics. The regressions are run for each year separately under the Klein and Spady (1993) binary response model and the time-series average of the coefficient estimates along with their associated time-series t-statistics are reported in the style of Fama and MacBeth (1973). Panel C reports regressions under Powell's (1986) truncated model, where the sample is truncated to only those observations for which bank financing is used. The dependent variable is the size of the loan as a fraction of the sale price. These regressions determine the relation between brokerage activity and the size of the loan. Again, the regressions are run separately for each year and the time-series average of the coefficient estimates and time-series t-statistics are reported in the style of Fama 
and MacBeth (1973). Both our theoretical predictions and our subsequent analysis illustrate the importance of examining the frequency of loan type separately from the size of the loan.

\section{Do Brokers Influence the Frequency of Bank Financing?}

Table II Panel B reports Fama-MacBeth regressions of the probability of obtaining bank financing on the instrumented measures of brokerage activity and the set of control variables. The regressions are conducted using a two-stage procedure. In the first stage the presence of a broker is estimated using the instruments and controls from Panel A under a linear probability model. ${ }^{14}$ In the second stage, the fitted (predicted) values from the first regression are used as explanatory variables in the probability of financing regression. The second stage regression is estimated under the Klein and Spady (1993) binary response model, in which the dependent variable is one if bank financing is used in the deal and zero otherwise. ${ }^{15}$

The results demonstrate a significant and influential role for brokers on the frequency of bank debt employed in the deal. The instrumented broker measure exhibits substantial explanatory power for the probability of obtaining bank financing, supporting the use of the selected instruments. The estimated probability of a bank loan in non-brokered transactions is 40 percent, in contrast to a 58 percent probability of a bank loan in the presence of a broker. (These probabilities are calculated at the median values of the exogenous variables.) The imputed increase in probability of obtaining bank debt from hiring a broker is thus a striking 18 percentage points, indicating an economically important impact from broker presence. These results are consistent with the broker-bank cooperation theory which predicts a higher frequency of new bank loans (Prediction 1). Of course, there may be many reasons why brokers seem to influence the likelihood of bank financing. We will argue in this and the next section that this influence arises from informal brokerbank relationships. But, in Section VI, we will present and test alternative theories regarding broker financial intermediation. Our conclusion, however, will be that it is these informal financial networks that play the key role in determining capital structure in this market. ${ }^{16}$

\footnotetext{
${ }^{14}$ This procedure is recommended by Angrist (2000).

${ }^{15}$ In addition to producing robust standard errors that account for cross-correlations in the residuals, the FamaMacBeth procedure, because it simply takes the time-series average of the coefficient estimates, implicitly produces standard errors that reflect the fact that the broker variables were estimated from the first-stage regression. Because the instrumented broker variables are themselves estimates, this will result in more variable slope coefficient estimates in the second stage regression, which will be accounted for in the Fama-MacBeth procedure by producing larger timeseries standard errors of those slope estimates.

${ }^{16}$ In an interesting recent development, the Federal Reserve and Treasury Department proposed that banks be permitted to offer real estate brokerage services (see, for example, The Wall Street Journal, January 25, 2001, p.
} 
We also examine the influence of brokers on the probability of new bank financing when no seller financing is provided. Although not an explicit prediction of our theory, one might expect that brokers would exploit their relationships with banks most strongly when they believe other forms of financing are unattainable. If sellers are simply not in a position to provide financing as a last resort, brokers may exert even greater effort with the bank to ensure the deal goes through. As Table II demonstrates, the effect of broker presence on new bank financing is three times stronger when no seller financing is present.

\section{Do Brokers Influence the Magnitude of Financing?}

Table II Panel C reports Fama-MacBeth regressions of the magnitude of new bank financing on a set of control variables as well as the instrumented measure of brokerage activity. The regression procedure is as above except that the dependent variable in the second stage regression is the size of the loan type, expressed as a fraction of the sale price. The second stage regression is run under Powell's (1986) truncated model, in which the sample is first truncated to only those observations with a positive dependent variable. The results demonstrate a slightly negative relation between the size of new bank loans and the presence of a broker. However, the effect is economically small. This is consistent with the broker-bank cooperation theory, which does not make an unambiguous prediction about loan size. In fact, the average loan size may be smaller since brokers prefer some financing to none at all in order to maximize the probability the deal is completed.

Finally, Panel D of Table II employs the non-instrumented endogenous broker variables in the bank financing regressions for comparison. The coefficients on the instrumented and noninstrumented broker variables are highly significant and similar in magnitude in the probability of bank financing regression, indicating that broker selection may not confound the likelihood of bank debt. However, in the truncated regression for the magnitude of the loan, the instrumented broker variable generates a much weaker relation between loan size and broker presence than the noninstrumented variable. This signifies both that broker selection may be important in this market, and that our instruments address the endogenous selection. We will revisit the potential influence of endogenous broker selection in Section VI.

A2). A regulatory change of this kind would likely disrupt the broker-bank cooperation we find, as banks would presumably favor their in-house brokerage firms. 


\section{Testing Broker-Bank Relationships and Their Influence on Fi- nancial Structure}

The previous regressions highlight an important role for brokers in increasing the likelihood of obtaining bank debt. While this result may be consistent with many theories of broker financial intermediation, we will argue in this section that brokers develop informal relationships with banks, which leads to their influence on property financing. In this section, we test directly whether brokers and banks have relationships and how this influences financial structure in the commercial real estate market.

\section{A. Do Brokers Have Relationships with Banks?}

\section{A.1 Broker-Bank Concentration}

If relationships between brokers and banks exist, then a given broker's deals should be concentrated among a few banks. Prediction 2 states that if relationships are important, then brokers will concentrate their deals among a smaller number of banks. To test this implication, we calculate two measures of broker concentration in banks. The first is the bank Herfindahl index for each broker, defined for broker $k$ as,

$$
\text { BankHerf }_{k}=\sum_{b \in B^{k}}\left(\frac{\# \text { Deals }_{k, b}}{\sum_{b \in B^{k}} \# \text { Deal }_{k, b}}\right)^{2},
$$

where $B^{k}$ is the set of banks that made loans to clients of broker $k$, and \#Deals $s_{k, b}$ is the number of deals brokered by broker $k$ that involved a loan from bank $b$. The second broker-bank concentration measure is the largest share of brokered deals involving bank debt that were completed by any one bank. For broker $k$ this is defined as,

$$
\text { BankShare }_{k}=\max _{\left\{b \in B^{k}\right\}}\left(\frac{\# \text { Deal }_{k, b}}{\sum_{b \in B^{k}} \# \text { Deal }_{k, b}}\right) .
$$

In order to determine whether brokers concentrate deals among certain banks, we compare the BankHerf and BankShare concentration measures for a particular broker to similar measures on a matched sample of deals that were not brokered. Since the location of the property, its type, and its size (price) may influence both the likelihood that it is brokered as well as the likelihood that bank financing is received, we form the matched sample of non-brokered properties to reflect these 
characteristics. Specifically, for each property brokered by broker $k$ that receives bank financing, we consider the set of non-brokered properties that also receive bank debt, are within 10 miles of the brokered property, and are of the same type (e.g., apartment, land, or commercial and industrial building). The property in this set closest in size to the brokered property is selected as the match. We compute the bank Herfindahl and bank share measures on this matched sample of firms, as above.

To be conservative and to produce a meaningful measure of concentration, we focus on brokers having at least 20 deals in our database. This covers roughly $80 \%$ of all brokered transactions. Broker-bank concentration measures higher than those of the matched sample provide evidence that brokers concentrate their deals among fewer banks than non-relationship-driven bank selection would suggest, supporting the broker-bank network hypothesis. To test for broker-bank concentration, we compute the difference between the true and matched sample concentration measures for each broker and average the differences across all brokers. If brokers do not concentrate their deals among certain banks in an unusual way, then this difference will be statistically indistinguishable from zero.

Table III reports this average difference across all brokers for both the Herfindahl and share concentration measures. The average BankHerf measure across brokers is slightly greater than 12 percent, while the Herfindahl measure of the matched sample is only 6.16 percent, resulting in a 6 percentage point difference that is statistically significant at less than the 0.5 percent level ( $t$ statistic $=3.47)$. Likewise, the average BankShare measure (21.89 percent) is 8.29 percent higher than the matched sample (13.60 percent) with a strong t-statistic of 4.08. This indicates strongly that brokers tend to concentrate their business among a few banks, supporting Prediction 2 and the existence of broker-bank networks.

However, there could be many reasons why brokers concentrate their deals among a few banks. For instance, transactions costs could produce the same outcome. To help distinguish our theory, Prediction 3 states that brokers with strong bank relationships will exert a larger influence on the granting of loans than the average broker. This should not be true if the motivation is to reduce transactions costs. To test this implication, we repeat the two-stage binary response regression from Table II of the probability of new bank financing on a set of control variables and the instrumented broker variable. In addition, we add an interaction term between the instrumented broker variable and whether the broker has strong ties with banks. As a measure of strong broker-bank relations, 
we define a concentration dummy variable equal to one if the broker's BankHerf measure is greater than its matched sample measure, and zero otherwise. This variable is multiplied by the instrumented broker presence variable to indicate whether brokers with stronger bank ties improve the likelihood of obtaining bank financing more than other brokers. The broker presence variables are again instrumented to control for the endogenous selection of brokers.

As Table III indicates, brokers with strong bank ties (high concentration measures) increase the probability of obtaining bank debt significantly more than other brokers do. This is consistent with Prediction 3 and suggests that the concentration measure represents the strength of broker-bank ties. Repeating this regression using the BankShare measures to compute a concentration dummy which equals one if a broker's BankShare is greater than his matched sample, we find the same result. Brokers who concentrate their deals among fewer banks, and thus likely have stronger ties with these banks, further improve their clients' probability of obtaining bank debt. Again, this is consistent with an informal network, but could also be consistent with an information story where brokers simply use a few good banks. However, as we will see in the next section, brokers are not using the same banks. Hence, each broker concentrates his business among a few banks, but these banks differ across brokers. This is inconsistent with an information story, but is compelling for our relationship story.

\section{A.2 Broker-Bank Longevity}

In addition to concentrating their deals among a select few banks, brokers will have greater influence on banks with which they have a longer relationship. As a measure of the longevity of the relationship between the broker and the bank, we find the earliest date when each broker-bank pair completed their first deal together and calculate from this the age of their relationship at the time of each subsequent deal. We compute the age of each relationship using only those deals taking place prior to 1997 and then apply these measures to a sample of transactions after 1997.

If brokers and banks develop informal relationships over time, then the fraction of the broker's deals devoted to a particular bank should increase over time. Prediction 4 states that the share of a broker's deals devoted to the bank will increase with the longevity of its relationship with the bank. To test this, we regress the share of the broker's deals involving a particular bank after 1997 on the length of their relationship (number of years since their first deal), measured prior to 1997. Table III indicates strongly that the longer the prior relationship with the bank, the 
more business the broker sends to the bank. This is consistent with the development of informal networks. Relationships, however, should work both ways. That is, not only should the broker's business become more concentrated over time among certain banks, but also the share of the bank's deals should be more concentrated among a select few brokers over time. Regressing the share of each bank's deals involving each broker on the longevity of their relationship, Table III documents a strong positive correlation, consistent with Prediction $5 .{ }^{17}$

Finally, if broker-bank relationships are important and if longevity helps capture the strength of such relationships, then we should see an even more significant impact on financial structure from brokers with longer bank relationships (Prediction 6). To test this, we regress the probability of obtaining a new bank mortgage on the instrumented broker presence variable plus an interaction term between the broker's age and the instrumented broker measure. Again, the dependent variable only contains transactions after 1997, while the broker longevity measure is estimated prior to 1997. (In other words, this is an out of sample test). The independent variables also include the buyer, seller, and property controls used previously plus state fixed effects. The regression is run under the Klein and Spady (1993) binary response model in the style of Fama and MacBeth (1973). As Table III indicates, the interaction term is highly significant and in fact eliminates the significance of the broker variable itself. Thus, brokers with long histories, who have cultivated bank relationships, greatly improve the future likelihood of obtaining bank debt for their clients, while young brokers, who have not established these relationships, do not increase the probability of bank financing significantly.

\section{Alternative Theories of Brokerage}

While the evidence for informal broker-bank relationships is quite strong, it may be that the results can be explained by other theories of brokerage. In this section we consider three alternate theories of broker intermediation. The first theory is that brokers may monitor the loan policies of banks and direct or advise their customers to seek loans from the bank most likely to provide financing. A second possibility is that brokers may certify the quality of properties and the creditworthiness of borrowers to lending institutions. Finally, despite our efforts to control for endogeneity, the endogenous selection of brokers by certain types of sellers may contribute to the observed relation between brokerage activity and financing. Specifically, liquidity-constrained sellers, anxious to

\footnotetext{
${ }^{17}$ Standard errors are computed using White's (1982) consistent error covariance estimator.
} 
complete a sale quickly, may be more likely to hire brokers and are less likely to provide seller finance.

\section{A. Advisory Services}

The first alternate theory argues that brokers monitor the loan-granting policies of various banks and encourage buyers to seek loans from the bank that can process a given loan with the highest probability. In this sense, brokers may provide a financial advisory service to buyers. Through their involvement with many deals, brokers obtain information about various bank lending policies and practices, and convey this information to their clients. Buyers in brokered transactions should therefore be more likely to receive bank finance. It may also be the case that banks recognize this fact and prioritize the processing of loans in brokered deals over loans in non-brokered deals. Hence, this model, like the relationship model, predicts that brokers increase the probability of obtaining bank financing (Prediction 1). As for the cooperation theory, however, the size of loans in brokered deals is not unambiguously predicted by this model.

The advisory service theory differs from the cooperation theory in several key respects. First, if brokers are searching across the universe of banks for the bank most likely to grant their client a loan, we would expect brokers to have dealings with a large number of banks, particularly if bank lending policies have changed over time. If certain banks become more competitive and offer better rates and easier credit, then their market share should increase. If brokers provide advisory services, then brokers should direct their clients to these banks. This could result in brokers spreading out deals across many banks over time, if bank policies change, or among a few banks if lending policies are stable and there are only a few banks worth directing business to. The important point is that brokered business should be relatively fickle and should be expected to flow towards the banks whose market shares are most increasing. Period-to-period brokered transaction volumes will vary greatly with total bank loan volumes.

On the other hand, if brokers and banks have long-term relationships, then brokerage business should be fairly steady and unwavering. Cooperation between banks and brokers should dampen short-term fluctuations in the loan business. Brokers will be loyal in consistently directing business to the same banks. In the equilibrium described in Result 1, cooperating brokers always send all their clients to the same bank. As a result, the elasticity of a bank's brokerage business with respect to its total loan business should be less than one. This leads to the following prediction. 
Prediction A1. If brokers provide advisory services, then the elasticity of a bank's brokerage business with respect to its total loan business will be greater than one. If banks and brokers cooperate, then this elasticity will be less than one.

We define brokers with elasticities less than one to be loyal. If brokers provide advisory services, then disloyal brokers, who presumably possess and exploit current market condition information, should be the most helpful in assisting their clients to find financing. If brokers and banks form relationships, then banks will only reward loyal brokers. In this case, clients of loyal brokers will be most advantaged in seeking bank loans. In the equilibrium outlined in Result 1, only cooperating brokers are loyal, and cooperating brokers most improve their clients' probability of receiving a loan.

Prediction A2. If brokers provide advisory services, then disloyal brokers will most improve their clients' probability of receiving a bank loan. If banks and brokers cooperate, then loyal brokers will most improve their clients' ability to secure bank finance.

If brokers make use of information to direct their clients to the source of financing that is currently most obliging, then brokerage clients should be expected to exhibit herding in their choice of banks. To the extent that brokers have useful information on the best banks to approach for a loan, this information must be correlated. Once a bank begins to offer more competitive terms and looser credit, many brokers will direct their clients to this bank. As new information arrives about certain banks, brokers and their clients will systematically flock to banks with the most attractive loan policies and away from those with unattractive ones. If brokers have relationships with banks, however, brokerage business will be fairly stable, and there is no reason to think all brokers will have relationships will the same bank.

Prediction A3. If brokers provide advisory services, brokers from different firms will herd in directing their clients to the same banks.

\section{A.1 Herding by Brokers into Banks}

As a direct test of the information/advisory service theory, we analyze whether brokers herd among banks. If information about bank loan policies drives broker selection of banks, then herding should be prevalent among brokers, as suggested by Prediction A3. To test this, we compute the following measure of herding by brokers in each bank. For bank $b$, the herding measure is, 


$$
\operatorname{Herd}_{b}=\left|\frac{\sum_{k \in K} \# \text { Deals }_{k, b}}{\# \text { Deals }_{b}}-\frac{\sum_{b \in B} \sum_{k \in K} \# \text { Deal }_{k, b}}{\sum_{b \in B} \# \text { Deals }_{b}}\right|-E(|\cdot|)
$$

where $K$ is the number of brokers and $B$ the number of banks in this market. This measure is the absolute value of the difference between the share of banks b's deals that are brokered and the share of all bank financed deals that are brokered. The term $E(|\cdot|)$ is an adjustment factor for the mean of this absolute difference to allow for random variation around the expected proportion of brokered deals under the null hypothesis of independent broker decisions on which bank to direct their clients. The herding measure in equation (9) is of the same flavor as those used by Lakonishok, Shleifer, and Vishny (1992) and Wermers (1999) to address stock herding in the money management industry. We follow both of these studies by computing the adjustment factor using simulations under a binomial distribution for each bank employing the actual proportion of brokered deals as the parameter in the simulations. ${ }^{18}$

Table IV reports the level of herding by brokers in banks. The average herding measure is 0.022 and is statistically greater than zero. Thus, there does appear to be some herding by brokers in banks, but it is not economically significant. This level of herding implies that on average, a bank to which brokers herd will transact two more brokered deals out of a hundred total deals than would be expected under random variation; and a bank to which brokers are not herding will transact two fewer brokered deals out of a hundred total deals. This is not particularly compelling, given that on average 65 deals out of a hundred are brokered. Herding is not generating a significant deviation from that average on a bank-by-bank basis.

It may be, however, that certain banks are herded into more than others. In particular, larger banks, for which information is more readily available, may have more herding, while small banks, for which information may be limited, may not. In addition as Peek and Rosengren (1996) discover, lending relationships tend to exist most strongly among small banks and smaller market participants. Hence, we would expect low or zero herding among small banks. Recomputing the herding measures for large (i.e., at least 10 deals) and small banks separately, we find that herding is non-existent among small banks, but is quite strong among the largest banks. This suggests that an information theory may only be relevant among large banks and deals, whereas relationships may be most important among small deals.

\footnotetext{
${ }^{18}$ The simulation details are provided in Wermers (1999) and are also available upon request.
} 


\section{A.2 Broker Loyalty to Banks}

To better distinguish between the advisory services or information theory and our theory of informal broker-bank relationships, we examine how loyal brokers are to the banks they have dealt with. Prediction A1 states that brokers will continue to send business to the banks they have relationships with, even when the bank's total volume declines (for any reason). In other words, if brokers have relationships with banks, we should see loyalty among brokered deals with banks. Conversely, if information about bank loan granting policies drives the relation between broker involvement and financial structure, then we would expect brokers to be disloyal to banks. Hence, broker business directed to the bank should be very sensitive to changes in the bank's loan policies or share of the market. If relationships exist, however, then brokers will be less sensitive to changes in the bank's business, and broker business directed to the bank will be sticky.

To test these conjectures, we compute the elasticity of the change in the broker's business directed to the bank with respect to the change in the bank's share of the commercial real estate loan market. The latter captures various factors affecting changes in the way the bank conducts business. More formally, for each broker-bank pair, we compute

$$
\begin{aligned}
\text { Elasticity }_{k, b} & =\frac{\% \Delta \theta_{k, b}}{\% \Delta \omega_{b}}=\frac{\left(\frac{\theta_{k, b}^{>1997}-\theta_{k, b}^{\leq 1997}}{\theta_{k, b}^{\leq 1997}}\right)}{\left(\frac{\omega_{b}^{>1997}-\omega_{b}^{\leq 1997}}{\omega_{b}^{\leq 1997}}\right)} \\
\theta_{k, b} & =\frac{\# \text { Deals } s_{k, b}}{\# \text { Deals }_{k}} \\
\omega_{b} & =\frac{\# \text { Deal } s_{b}}{\sum_{b \in B} \# \text { Deals } s_{b}}
\end{aligned}
$$

where $\% \Delta \theta_{k, b}$ is the percentage change in broker $k$ 's share of deals devoted to bank $b$ and $\% \Delta \omega_{b}$ is the percentage change in bank $b$ 's share of the market. Changes are estimated by splitting the sample before and after January 1, 1997. Alternatively, this measure can be viewed as the coefficient from a regression of $\% \Delta \theta_{k, b}$ on $\% \Delta \omega_{b}$. An elasticity less than 1 indicates that the broker's share devoted to the bank is less sensitive than the market's fickleness toward that bank (e.g., the broker is more loyal to the bank than the market). An elasticity of equal to or greater than 1 suggests the broker is equally or more sensitive than the market. We designate this a disloyal relationship.

Table IV reports that the average elasticity measure across all broker-bank relationships is statistically no different from 1 . This suggests either brokers are not loyal or perhaps that some 
brokers are loyal and some are not, resulting in an average elasticity of 1. Moreover, brokers may have informal relationships with some banks but not others, resulting in some loyal partnerships and some disloyal interactions. To test this, we split the sample into the smallest (less than $\$ 10$ million) and largest deals. Relationships are more likely exhibited among smaller deals. Table IV documents that this is indeed the case as the average elasticity among this group is 0.80 and statistically less than 1 at the $1 \%$ significance level. Large deals, on the other hand, exhibit an elasticity greater than 1. These findings mirror those found on herding and suggest that informal relationships exist, but are primarily concentrated among the smaller deals, where such relationships are likely most needed and most valuable. Among the larger deals, disloyalty and herding occur, suggesting that information issues may be more pertinent among the largest deals.

Although some relationships may be loyal and some disloyal, and some brokers may be systematically loyal or disloyal, the important question is whether loyalty or disloyalty improves the probability of receiving financing. If brokers have better information about bank loan policies, then disloyalty (an indicator of new information about banks) should increase the probability of obtaining bank debt, according to Prediction A2. Our relationship or cooperative theory, however, makes exactly the opposite prediction. If relationships are important in this market, then loyal brokers will greatly improve the probability of receiving bank financing and disloyalty should reduce the likelihood of garnering bank debt.

To test the impact of loyalty on financial structure, we identify brokers as being loyal or disloyal via their average elasticity measure across the banks they deal with. Dummy variables for loyalty (elasticity less than 1) and disloyalty (elasticity greater than 1) are created and interacted with the instrumented broker presence variable to be employed as regressors in the binary response regression of the probability of new mortgage financing. Once again, the loyalty measures are calculated using data prior to 1997 and applied to property transactions after 1997, thus avoiding any overlapping sample biases. The regressions are run under the Klein and Spady (1993) model in the style of Fama and MacBeth (1973) and include all of the buyer, seller, and property controls, as well as state dummies, used previously. These coefficient estimates are not reported for brevity.

As Table IV reports, loyal brokers significantly improve the likelihood of receiving a bank loan, while disloyal brokers significantly decrease the probability of obtaining bank debt. This is compelling evidence that broker loyalty is important and strongly supports the hypothesis of informal broker-bank networks pervading this market and influencing capital structure. For robustness, we 
also repeat these regressions using a broker loyalty measure derived from the dollar volume of broker deals directed to the bank as opposed to the number of transactions. The regressions generate an even stronger impact on financial structure from broker loyalty and negative effect from disloyalty. This is again compelling evidence that informal relationships not information/advisory services explain the relation between brokerage activity and financial structure.

\section{B. Certification}

The second alternate theory we investigate argues that brokers serve a certification role similar to that of venture capitalists (Brav and Gompers (1997)) or commercial and investment banks (Puri (1994) and Lizzeri (1999)). The analogy to investment bankers is particularly close, since typically neither brokers nor investment bankers have significant equity stakes in the assets they certify. Broker certification will result in brokered transactions receiving loans more frequently and

receiving larger loans, as the certified pool is of higher quality than the non-brokered pool. The presence of a broker should therefore encourage bank finance. More formally,

Prediction B1. Brokered deals are more likely to receive bank financing, and the size of bank loans will be greater for brokered deals.

Although the first part of Prediction B1 is consistent with the data, the size of bank loans is marginally negatively affected by the presence of a broker. In addition, the results on broker concentration in banks, broker-bank longevity, and broker loyalty do not seem related at all to a certification story.

Unlike the first two models, this model makes a prediction about the price of the property. Broker certification reduces the information discount associated with selling a property and should therefore lead to higher average prices.

Prediction B2. Properties sold through the agency of a broker will receive higher average prices.

\section{Broker Selection}

Finally, despite our efforts to control for endogenous broker selection via instrumental variables, the third alternate theory is that brokers are hired by liquidity-constrained sellers. Knoll (1988) and Yang and Yavas (1995) document that the average time on the market is lower for brokered 
properties. Therefore, sellers who are liquidity constrained may be willing to pay the brokerage commission in exchange for a more rapid sale. Such sellers, however, will be very reluctant to provide VTB financing.

Prediction C1. Brokered deals will exhibit less VTB financing.

Liquidity constrained sellers will also be willing to accept lower prices in exchange for much needed current cash flows.

Prediction C2. Properties sold through the agency of a broker will receive lower average prices.

Although most of our findings are not consistent with either of these last two theories, we attempt to examine their predictions directly by testing broker's influence on other forms of financing and on market prices. This will also provide additional tests on the strength of the relationship hypothesis.

\section{Do Brokers Influence Other Forms of Financing?}

Using the two-stage binary response and truncated regressions, we evaluate whether broker presence influences the frequency and magnitude of other forms of financing. We examine the presence and magnitude of vendor (VTB) financing, VTB financing when no bank financing is present, and the probability of assuming an existing mortgage. ${ }^{19}$ Once again, we instrument brokerage activity and compute estimates in the style of Fama and MacBeth (1973). As Table V reports, exogenous broker presence has little impact on the presence of VTB financing, but decreases its size. This contradicts the certification and liquidity-constrained seller explanations. Moreover, conditional on no bank financing being present, the frequency of VTB increases but the size of the loan granted decreases significantly, consistent with Prediction 7. Finally, the probability of assuming an existing mortgage also increases with broker presence. This is consistent with a relationship theory (Prediction 8) but is not predicted by any other theory.

\section{E. Broker Selection and the Influence on Sale Prices}

Finally, we examine whether brokers influence the market prices of commercial properties. Table VI reports the results of Fama-MacBeth regressions of property capitalization rates on the various instrumented measures of brokerage activity and control variables. The same two stage procedure

\footnotetext{
${ }^{19}$ The size of an existing mortgage obviously cannot be chosen.
} 
is conducted, in which the second stage is estimated via least squares, since cap rates are neither censored nor truncated. As Table VI indicates, there is virtually no effect on price from brokerage activity once endogenous broker selection is taken into account. This generally negative result is striking, given that increasing the sale price is one of the primary brokerage functions described in the literature. Neither the cooperation nor advisory theories make predictions about brokers influencing prices. The certification story, however, predicts that brokered deals will have higher prices (Prediction B2) while the endogenous selection of brokers by liquidity-constrained sellers predicts that brokered deals have lower prices (Prediction C2).

As a direct test of broker selection, we also report the cap rate and probability of VTB financing regressions using the non-instrumented broker presence variable. Comparing the endogenous broker variable results with those employing the instruments, we see evidence of broker selection. The presence of brokers is consistently related to lower priced properties, but accounting for endogenous broker selection with the instruments there is no significant broker influence on price. Hence, the relation between brokerage activity and price appears to be entirely driven by the type of sellers who choose brokers. The results are inconsistent with the broker certification theory, however. Equally compelling is the negative effect of broker presence on the probability of vendor financing when no endogenous selection is taken into account. Prediction C1 states that brokered deals will exhibit less VTB financing if liquidity constrained sellers tend to hire brokers. When employing the instrumented broker variable in Table VI, however, this relation disappears. Thus, broker selection does appear to be important in this market, but our use of instruments seems to account for the endogenous selection.

Table VII summarizes the theoretical predictions of the various models and whether they were verified in our data. Accumulating all of the evidence, it appears that broker-bank networks have an important impact on financing, and that cultivating relationships with lenders is an additional valuable service provided by service intermediaries for their clients.

\section{Conclusion}

In this paper we present a model of informal financial networks and substantiate the model's main predictions in an empirical study of patterns of financing in the U.S. commercial real estate market. We find that informal networks play a significant role in determining access to finance. 
Our model provides a formal analysis of the financial role of service intermediaries in markets in which borrowers seek loans infrequently and are therefore unable to establish cooperation with lenders. In our empirical analysis, we show that property broker involvement strongly increases the probability that bank debt will be granted. Broker-bank relationships are found to be the most significant feature of the market, and other theories of intermediation perform less well in explaining the data.

The informal financial intermediation described in this paper is of significant importance in many settings, but it has not received sustained theoretical or empirical attention in the literature. In the small business market, lawyers provide professional services to their clients and may also aid them in finding private equity or bank loan capital. An accountant or consultant may serve as a client's connection to a local angel network. Small firms often receive guidance in seeking finance from suppliers or customers. In developing countries various middlemen direct producers and farmers to sources of finance. This paper analyzes the role of informal intermediaries and demonstrates that they can be critical in providing access to finance. The results of the paper indicate that informal financial networks can have a powerful influence on credit markets and hence on real economic activity, even in highly-developed economies such as the U.S. 


\section{Appendix}

\section{A. Proof of Results}

\section{A.1 Result 1}

Proof: Consider the strategies described in the statement of the result. We will show that no deviation is optimal in any subgame of the lending game. Short-term service intermediaries and buyers in deals without a service intermediary know that all lenders will handle their applications in the standard manner and bargain over the interest rate in the same (time-invariant) way. They are therefore indifferent to the choice of lender.

Long-run non-cooperative service intermediaries face a similar choice. Since no change in its strategy will alter the current or future behavior of any lender, a service intermediary is indifferent between all lenders. Long-run cooperative service intermediaries in a dyadic relationship raise their clients' probability of receiving expedited evaluation (and hence raise the probability that the service intermediary will receive its fee), by sending all their clients to the lender with whom they have a relationship. This strategy also guarantees that the service intermediary's future clients will have access to expedited evaluation. All other lenders will always provide the service intermediary's clients with standard evaluation, irrespective of the service intermediary's current or future advice. If the lender with which the service intermediary shares a dyadic relationship has defected in the past by not offering one of the service intermediary's clients expedited evaluation, then the lender will never offer any of the service intermediary's clients expedited evaluation in the future, and the service intermediary is just as well off by recommending other lenders to its clients. Clients of service intermediaries in a cooperative dyadic relationship benefit from an expedited evaluation when they follow their service intermediary's advice. All other buyers are indifferent about taking their service intermediary's recommendation.

Next, we consider the strategies of lenders. Given a loan request from a buyer who is not a client of a service intermediary with whom the lender has a dyadic relationship, the lender's choice of standard or expedited evaluation will not affect any future payoffs; short-run players select lenders randomly and the recommendations of long-run service intermediaries with whom the lender does not have a dyadic relationship are not affected by the lender's current decision. Condition (3) guarantees that the lender prefers to offer these applicants standard evaluation. 
Now let us consider the lender's decision whether or not to expedite the loan requests of the clients of a service intermediary with whom the lender has a dyadic relationship. We will consider only the profits arising from the lender's relationship with the service intermediary, since all other profits are unaffected. Suppose the service intermediary has $\hat{l}_{s}$ clients this period, all of whom he directs to the bank. If the lender evaluates even one of the clients' applications in the standard manner, it will receive no future clients from the service intermediary. Since evaluating applications in the expedited way is costly in the short-run, if the lender elects to evaluate at least one of the applications in the standard manner, it does best to evaluate them all in the standard manner, for which it will receive

$$
\hat{l}_{s}\left(-e_{0}+\frac{q v}{2}\right)
$$

If the lender evaluates all the applications in an expedited manner and follows its proposed equilibrium strategy, it expects that it will receive at least one application per period from this service intermediary ( ince $l_{s} \geq 1$ in every period), so its payoff is at least

$$
\hat{l}_{s}\left(-e_{1}+\frac{p v}{2}\right)+\frac{\delta\left(-e_{1}+\frac{p v}{2}\right)}{1-\delta} .
$$

For $\delta \rightarrow 1$, the second term in equation (A2) rises to infinity, showing that for $\delta$ sufficiently high the lender will cooperate and expedite all the service intermediary's clients' requests.

Given that both buyers and lenders propose a repayment of $\frac{I+\frac{v}{2}}{\delta}$, their strategies in the bargaining part of the game are also optimal. Since self-financing leaves the buyer with $v-c \leq \epsilon<\frac{v}{2}$ (exclusive of service intermediary fees), lender financing is always preferable to self-financing. Good buyers who are rejected by a lender will self-finance if their residual $v-c$ exceeds zero if they have no service intermediary or if it exceeds $f$ if they have a service intermediary. This establishes that the described profile of strategies does constitute a subgame perfect equilibrium.

\section{A.2 Result 2}

Proof: Let us consider a candidate equilibrium in which the lender provides an expedited evaluation of the application of a player of either of the two types described in the statement of the result. Suppose the lender changes its strategy by not providing this player with an expedited evaluation. Condition (3) shows that the lender will strictly improve its payoff in the current period. Further- 
more, since the lender's decision is not observed by any player who plays in a future period, the strategies of all such players cannot condition on the lender's action this period. This implies that the lender's future payoffs in all periods are unaffected. This shows that a deviation is profitable, so the candidate equilibrium is not an equilibrium.

\section{B. Semiparametric Binary Response Model}

First, we consider only the presence or absence of the dependent variable. For example, we set $y_{n}=1$ if a positive amount of VTB financing is used in the $n$th deal, and we set $y_{n}=0$ if no VTB is used in the deal. We then consider a binary response model of the following form

$$
\begin{aligned}
& y_{n}^{*}=\beta^{\prime} x_{n}+u_{n} \\
& y_{n}=1 \text { if } y_{n}^{*} \geq 0 \\
& y_{n}=0 \text { otherwise }
\end{aligned}
$$

where $x_{n}$ is a $q \times 1$ vector of explanatory variables, $\beta$ is a $q \times 1$ vector of parameters, $u_{n}$ is a random error term and $n=1, \ldots, N$. Although a probit or logit model may be used to estimate this system, several simulation studies have shown that both of these models may be radically biased when the error distribution is not normal or logistic, respectively (see Gerfin (1996) for a general discussion of these studies). Economic theory does not propose any particular distribution for the error term. It is therefore better to estimate (A3) using the semiparametric single-index model of Klein and Spady (1993), which allows the error distribution to be unspecified. This model presumes that

$$
P\left(y_{n}=1 \mid x_{n}\right)=F\left(\beta^{\prime} x_{n}\right)
$$

where $F$ is an unknown function whose range is contained in $[0,1]$. The term $\beta^{\prime} x_{n}$ is referred to as the index. ${ }^{20}$ The intercept component of $\beta$ is subsumed in $F$ and is therefore not estimated. This model accommodates any form of heteroscedasticity that is consistent with (A4). The estimator of $\beta$ is the argument that maximizes the quasi-log-likelihood function

$$
\log L_{N}(b)=\sum_{n=1}^{N}\left[y_{n} \log F_{N}\left(b^{\prime} x_{n}\right)+\left(1-y_{n}\right) \log \left(1-F_{N}\left(b^{\prime} x_{n}\right)\right)\right]
$$

where $F_{N}$ is a nonparametric kernel estimate of $F$. We follow Klein and Spady (1993) and set $F_{N}$ in equation (A5) equal to a nonparametric kernel estimate of $F$. We use the adaptive local smoothing

\footnotetext{
${ }^{20}$ See Horowitz (1998) for a general discussion of single-index models.
} 
estimator and define the kernel function to be $K(v)=(3 / 22)\left(1(-1 / 5) v^{2}+(7 / 625) v^{4}\right) 1(|v| \leq 5)$. The term $F_{N}$ is estimated in two steps. In the first step, we define

$$
G_{N}\left(v_{i}, \beta\right)=\frac{\sum_{j=1}^{N} \frac{y_{j}}{h_{P}} K\left(\frac{v_{i}-\beta^{\prime} x_{j}}{h_{P}}\right)}{\sum_{j=1}^{N} \frac{y_{j}}{h_{P}} K\left(\frac{v_{i}-\beta^{\prime} x_{j}}{h_{P}}\right)+\sum_{j=1}^{N} \frac{1-y_{j}}{h_{P}} K\left(\frac{v_{i}-\beta^{\prime} x_{j}}{h_{P}}\right)},
$$

where $h_{P}$ is the pilot window size. The estimate of $F_{N}$ is not very sensitive to the choice of $h_{P}$; we set $h_{P}=1.5$. The function $G_{N}$ serves as a preliminary estimate of the density function. In the second stage we define $l_{y j}=G_{N}\left(\beta^{\prime} x_{j}, \beta\right)$ and set $m$ equal to the geometric mean of the $l_{y j}$. We then set $L_{y j}=\left(\frac{l_{y j}}{m}\right)^{\left(-\frac{1}{2}\right)}$. We define $h_{N j}=\left(h_{N}\right)\left(\hat{\sigma}_{y_{j}}(\beta)\right)\left(L_{y j}\right)$, where $\hat{\sigma}_{y_{j}}(\beta)$ is the sample standard deviation of $\beta^{\prime} x$ conditional on $y_{j}$ and $h_{N}$ is the window size. We set $h_{N}=N^{\left(-\frac{1}{7.98}\right)}$, which satisfies Klein and Spady's condition for window sizes. We then define

$$
F_{N}\left(v_{i}, \beta\right)=\frac{\sum_{j=1}^{N} \frac{y_{j}}{h_{N j}} K\left(\frac{v_{i}-\beta^{\prime} x_{j}}{h_{N j}}\right)}{\sum_{j=1}^{N} \frac{y_{j}}{h_{N j}} K\left(\frac{v_{i}-\beta^{\prime} x_{j}}{h_{N j}}\right)+\sum_{j=1}^{N} \frac{1-y_{j}}{h_{N j}} K\left(\frac{v_{i}-\beta^{\prime} x_{j}}{h_{N j}}\right)} .
$$

Following Horowitz (1993) and Gerfin (1996), we do not use trimming to downweight extreme observations as is required by the theory, since trimming appears to have a very minor effect in applications.

As is standard in binary response models (including probit), $\beta$ can only be identified up to a scale normalization which is typically achieved by setting one coefficient equal to one. Klein and Spady (1993) show that the estimator of $\beta$ is consistent and asymptotically normal. This estimator performed well in simulations studied by Klein and Spady (1993) and in Gerfin's (1996) labor market application.

\section{Truncated Regression Model}

Our second mode of analysis is to consider only those data points $\left(y_{n}^{*}, x_{n}\right)$ for which $y_{n}^{*}>0$. That is, only data points with a positive amount of the dependent variable are considered, while data points for which $y_{n}^{*} \leq 0$ are discarded. A truncated regression model applies to this restricted sample. Formally,

$$
y_{n}=\beta^{\prime} x_{n}+v_{n},
$$

where $v_{n}$ has the conditional distribution of $u_{n}$ given $u_{n}>-\beta^{\prime} x_{n}$. Powell (1986) proposes a symmetrically truncated least squares estimator of this model that is consistent and asymptotically 
normal under the assumption that the error terms $u_{n}$, conditional on $x_{n}$, are symmetrically distributed and unimodal. The errors are permitted to be subject to heteroscedasticity of an unknown form. The estimator of $\beta$ is defined to be the minimizer of

$$
R_{N}(b)=\sum_{n=1}^{N}\left(y_{n}-\max \left\{\frac{y_{n}}{2}, b^{\prime} x_{n}\right\}\right)^{2} .
$$

For the financing regressions, we will presume that the total financing cannot exceed one hundred percent of the sale price. The correct model is therefore given by

$$
y_{n}=\min \left\{\beta^{\prime} x_{n}+v_{n}, 1\right\}
$$

The upper limit of 100 percent financing does not bind in most of our regressions. In cases where the upper limit does bind, however, we use Powell's (1986) censored and truncated estimator. This estimator of $\beta$ is defined to be the minimizer of

$$
\begin{aligned}
Q_{N}(b) & =\sum_{n=1}^{N} 1\left(b^{\prime} x_{n}<\frac{1}{2}\right)\left(y_{n}-\max \left\{\frac{y_{n}}{2}, b^{\prime} x_{n}\right\}\right)^{2} \\
& +\sum_{n=1}^{N} 1\left(b^{\prime} x_{n} \geq \frac{1}{2}\right)\left(y_{n}-\min \left\{\frac{y_{n}+1}{2}, b^{\prime} x_{n}\right\}\right)^{2} \\
& +\sum_{n=1}^{N} 1\left(b^{\prime} x_{n}>\frac{1+y_{n}}{2}\right)\left(\frac{\left(y_{n}-1\right)^{2}}{4}\left(-\min \left\{0, b^{\prime} x_{n}-1\right\}\right)^{2}\right),
\end{aligned}
$$

where $1(B)$ denotes the indicator function of the event $B$. 


\section{References}

Angrist, Joshua D., "Estimation of Limited-Dependent Variable Models With Dummy Endogenous Regressors: Simple Strategies for Empirical Practice," Technical Working Paper 248, National Bureau of Economic Research (2000).

Brav, Alon, and Paul A. Gompers, "Myth or Reality? The Long-Run Underperformance of Initial Public Offerings: Evidence from Venture and Nonventure Capital-Backed Companies," Journal of Finance, LII (1997), 1791-1821.

Burkett, Paul, "Informal Finance in Developing Countries: Lessons for the Development of Formal Financial Intermediaries," Journal of Economic Development, XIII (1988), 81-110.

Cobham, David, and Ramesh Subramaniam, "Corporate Finance in Developing Countries: New Evidence for India," World Development, XXVI (1998), 1033-1047.

Coval, Joshua D., and Tobias J. Moskowitz, "Home Bias at Home: Local Equity Preference in Domestic Portfolios,", Journal of Finance, LIV (1999), 2045-2074.

Diamond, Douglas, "Financial Intermediation and Delegated Monitoring," Review of Economic Studies, LI (1984), 393-414.

Fama, Eugene and Kenneth R. French, "Disappearing Dividends: Changing Firm Characteristics or Lower Propensity to Pay?", CRSP Working paper, University of Chicago (2000).

Fama, Eugene and James MacBeth, "Risk, return, and equilibrium: Empirical tests", Journal of Political Economy LXXI (1973), 607-636.

Garmaise, Mark J., and Tobias J. Moskowitz, "Confronting Information Asymmetries: Evidence from Real Estate Markets," Working Paper, University of Chicago (2000a).

Garmaise, Mark J., and Tobias J. Moskowitz, "Crime, Race and Commercial Real Estate," Working Paper, University of Chicago (2000b).

Gerfin, Michael, "Parametric and Semi-Parametric Estimation of the Binary Response Model of Labour Market Participation," Journal of Applied Econometrics, XI (1996), 321-339.

Godley, Andrew, and Duncan M. Ross, "Introduction: Banks, Networks and Small Firm Finance," Business History, XXXVIII (1996), 1-10.

Horowitz, Joel L., "Semiparametric Estimation of a Work-Trip Mode Choice Model," Journal of Econometrics, LVIII (1993), 49-70.

Horowitz, Joel L., Semiparametric Methods in Econometrics (New York, NY : Springer-Verlag, 1998).

Janssen, C. T. L., and J.D. Jobson, "On the Choice of Realtor," Decision Sciences, XI (1980), 299-311.

Jud, G.D., and J. Frew, "Real Estate Brokers, Housing Prices, and the Demand for Housing," Urban Studies, XXIII (1986), 21-31.

Kandori, Michihiro, "The Use of Information in Repeated Games with Imperfect Monitoring," Review of Economic Studies, LIX (1992), 581-593.

Klein, Roger W., and Richard H. Spady, "An Efficient Semiparametric Estimator for Binary Response Models," Econometrica, LXI (1993), 387-421. 
Krasa, Stefan, and Anne P. Villamil, "Monitoring the Monitor: An Incentive Structure for a Financial Intermediary," Journal of Economic Theory, LVII (1992), 197-221.

Lizzeri, Alessandro, "Information Revelation and Certification Intermediaries," Rand Journal of Economics, XXX (1999), 214-231.

Mason, Colin M., and Richard T. Harrison "Business Angel Networks and the Development of the Informal Venture Capital Market in the U.K.: Is There Still a Role for the Public Sector," Small Business Economics, IX (1997), 111-123.

Nothaft, Frank E., and Janice S. Westfall, "Survey of Home-Seller Finance," Federal Reserve Bulletin, LXXI (1985), 767-775.

Peek, Joe, and Eric S. Rosengren, "Small Business Credit Availability: How Important is Size of Lender," in A. Saunders and I. Walter, eds., Financial System Design: The Case for Universal Banking (Burr Ridge : Irwin, 1996).

Powell, James L., "Least Absolute Deviations for the Censored Regression Model," Journal of Econometrics, XXV (1984), 303-325.

Powell, James L., "Symmetrically Trimmed Least Squares Estimation for Tobit Models," Econometrica, LIV (1986), 1435-1460.

Puri, Manju, "On the Long-Term Default Performance of Bank Underwritten Security Issues," Journal of Banking and Finance, XVIII (1994), 397-418.

Puri, Manju, "Commercial Banks in Investment Banking: Conflict of Interest or Certification Role?" Journal of Financial Economics, XL (1996), 373-401.

Stahl, David, "Teaming Up," Savings and Community Banker, II (1993), 68-69.

Ville, Simon, and Grant Fleming, "The Nature and Structure of Trade-Financial Networks: Evidence from the New Zealand Pastoral Sector," Business History, XLII (2000), 41-58.

Werner, Claude, "Debt Capital Remains Available Despite Market Changes," Commercial Investment Real Estate, January-February (2000).

Wilder, Jeff. "Creative Financing Can Facilitate Transaction Closings," Hotel and Motel Management, CCX (1995), 30,32.

Williams, Joseph T., "Agency and Brokerage of Real Assets in Competitive Equilibrium," Review of Financial Studies, XI (1998), 239-280.

Zinn, James M., "Achieving Sale Treatment for Sales of Real Estate Owned," Commercial Lending Review, VII (Winter 1991-1992), 71-75.

Zumpano, Leonard, Harold Elder and Edward Baryla, "Buying a House and the Decision to Use a Real Estate Broker," Journal of Real Estate Finance and Economics, XIII (1996), 169-181. 
Table I:

\section{Summary Statistics of the U.S. Commercial Real Estate Market}

Descriptive statistics on the COMPS commercial real estate transactions from the U.S. over the period January 1, 1992 to March 30, 1999 are reported below. Panel A reports general characteristics of the properties in the database, reporting the number of sales, average age of the property, percentage of properties planned for development (Dev.), average capitalization rate (defined as net operating income divided by sales price), and local (county) crime index scores for crimes against property and person, obtained from CAP Index, Inc. Panel B reports information on participation in the commercial real estate market, reporting the mean and median distance buyers are from the property, percentage of buyers from out of state, mean and median distance sellers are from the property, percentage of sellers from out of state, as well as the percentage of sales that employed a broker and where a broker bought or sold on his own behalf. Panel C contains financing information on the real estate transactions. The three types of financing are vendor-to-buyer (VTB), assumed mortgage, and new mortgage. The mean sale price is reported and the frequency of each type of financing is reported as a percentage of the total number of transactions, as well as the percentage of the sale price each type of financing comprises when it is used. In addition, the sum of all financing used as a fraction of the sale price is reported (total loan/value). Both general statistics and financing information are reported for the whole sample, for transactions within and outside of the largest metropolitan areas (City-Centerdefined as the largest city or cities in each state), for the smallest and largest half of deals, and for apartments (Apt), vacant land (Land), and commercial and industrial buildings (Comm. \& Ind.) separately.

\begin{tabular}{|c|c|c|c|c|c|c|c|c|}
\hline & All & $\begin{array}{r}\text { City } \\
\text { Center }\end{array}$ & $\begin{array}{l}\text { Non } \\
\text { City }\end{array}$ & $\begin{array}{l}\text { Small } \\
\text { Deals }\end{array}$ & $\begin{array}{l}\text { Large } \\
\text { Deals }\end{array}$ & Apt. & Land & $\begin{array}{r}\text { Comm.\& } \\
\text { Ind. }\end{array}$ \\
\hline \multicolumn{9}{|c|}{ Panel A: Property Characteristics } \\
\hline \# Sales & 22,642 & 10,815 & 11,827 & 11,325 & 11,317 & 7,924 & 4,134 & 10,584 \\
\hline $\mathrm{Age}^{\dagger}$ & 35.48 & 42.49 & 28.85 & 39.85 & 31.19 & 37.78 & 35.65 & 33.63 \\
\hline Development & $6.33 \%$ & $4.74 \%$ & $7.78 \%$ & $5.40 \%$ & $7.26 \%$ & $3.50 \%$ & $16.30 \%$ & $4.70 \%$ \\
\hline Cap. Rate $\dagger$ & $9.35 \%$ & $9.58 \%$ & $9.12 \%$ & $9.16 \%$ & $9.53 \%$ & $10.01 \%$ & $7.59 \%$ & $8.26 \%$ \\
\hline Personal Crime rate & 1.52 & 1.69 & 1.36 & 1.62 & 1.41 & 1.50 & 1.48 & 1.55 \\
\hline Property Crime rate & 1.92 & 2.37 & 1.50 & 1.99 & 1.85 & 2.04 & 1.60 & 1.94 \\
\hline \multicolumn{9}{|c|}{ Panel B: Market Participants } \\
\hline $\begin{array}{l}\text { Buyer Distance } \\
\text { (median) }\end{array}$ & $\begin{array}{r}193.62 \\
(38.47)\end{array}$ & $\begin{array}{r}198.72 \\
(39.90)\end{array}$ & $\begin{array}{r}188.96 \\
(37.76)\end{array}$ & $\begin{array}{r}113.35 \\
(35.80)\end{array}$ & $\begin{array}{r}273.95 \\
(41.86)\end{array}$ & $\begin{array}{r}170.42 \\
(36.46)\end{array}$ & $\begin{array}{r}203.87 \\
(37.40)\end{array}$ & $\begin{array}{r}206.04 \\
(40.57)\end{array}$ \\
\hline Buyer Out of State & $11.84 \%$ & $11.84 \%$ & $11.84 \%$ & $6.38 \%$ & $17.29 \%$ & $8.99 \%$ & $15.43 \%$ & $12.56 \%$ \\
\hline Seller Distance & 255.34 & 248.79 & 261.32 & 195.94 & 314.77 & 221.01 & 231.37 & 290.17 \\
\hline (median) & $(42.87)$ & $(43.60)$ & $(42.34)$ & $(40.65)$ & $(45.45)$ & $(40.41)$ & $(41.55)$ & $(44.94)$ \\
\hline Seller Out of State & $16.34 \%$ & $16.26 \%$ & $16.41 \%$ & $12.10 \%$ & $20.58 \%$ & $11.75 \%$ & $18.05 \%$ & $19.15 \%$ \\
\hline Broker Present & $65.23 \%$ & $67.07 \%$ & $63.55 \%$ & $63.65 \%$ & $66.82 \%$ & $76.81 \%$ & $46.71 \%$ & $63.38 \%$ \\
\hline Buyer is Broker & $3.22 \%$ & $4.04 \%$ & $2.46 \%$ & $3.25 \%$ & $3.18 \%$ & $4.47 \%$ & $3.48 \%$ & $2.14 \%$ \\
\hline Seller is Broker & $2.69 \%$ & $3.26 \%$ & $2.17 \%$ & $2.68 \%$ & $2.70 \%$ & $2.73 \%$ & $3.68 \%$ & $2.28 \%$ \\
\hline \multicolumn{9}{|c|}{ Panel C: Financial Structure } \\
\hline Sale Price $(\$, 000)$ & $\$ 2,386$ & $\$ 2,814$ & $\$ 1,995$ & $\$ 355$ & $\$ 4,419$ & $\$ 1,843$ & $\$ 1,491$ & $\$ 3,134$ \\
\hline New Mortgage (freq. \%) & $52.16 \%$ & $53.74 \%$ & $50.71 \%$ & $52.54 \%$ & $51.77 \%$ & $68.95 \%$ & $25.11 \%$ & $49.85 \%$ \\
\hline New Mortgage (\% Price) & $72.59 \%$ & $70.94 \%$ & $75.18 \%$ & $76.57 \%$ & $72.21 \%$ & $75.60 \%$ & $71.51 \%$ & $71.16 \%$ \\
\hline Vendor-to-Buyer (freq. \%) & $18.80 \%$ & $19.47 \%$ & $18.18 \%$ & $23.21 \%$ & $14.39 \%$ & $17.66 \%$ & $17.59 \%$ & $20.00 \%$ \\
\hline Vendor-to-Buyer (\% Price) & $59.54 \%$ & $60.64 \%$ & $58.15 \%$ & $63.27 \%$ & $58.68 \%$ & $50.72 \%$ & $70.92 \%$ & $61.17 \%$ \\
\hline Assm. Mortgage (freq. \%) & $5.32 \%$ & $5.71 \%$ & $4.96 \%$ & $5.03 \%$ & $5.60 \%$ & $9.59 \%$ & $1.28 \%$ & $3.65 \%$ \\
\hline Assm. Mortgage (\% Price) & $67.37 \%$ & $69.42 \%$ & $65.26 \%$ & $72.23 \%$ & $67.11 \%$ & $70.61 \%$ & $74.53 \%$ & $64.10 \%$ \\
\hline Loan-to-Value ratio & $72.57 \%$ & $71.19 \%$ & $74.62 \%$ & $78.04 \%$ & $71.99 \%$ & $74.94 \%$ & $73.60 \%$ & $71.10 \%$ \\
\hline
\end{tabular}

$\dagger$ Averages are computed only among those properties containing age and capitalization rate information. 


\section{Predicting Brokerage Activity and its Influence on Obtaining Bank Financing}

Several exogenous instruments are used to identify brokerage activity: the population density radius of the local market, defined as the minimum of the mile radius which encompasses 100,000 people or 3 miles, a crime index score for crimes against persons (homicide rate), obtained from Cap Index, Inc., the capitalization rate or scaled price variance of the local market (for all properties within a 10 mile radius, excluding the property itself), the dollar fraction of brokered deals conducted by a national broker within a 10 mile radius, and the Herfindahl index of brokerage activity within a 10 mile area. Panel A reports the regression coefficients on the instruments from this instrumented variable regression of brokerage activity. In addition to the instruments, the regressors include a dummy for non-corporate buyers, seller and buyer distance, dummies for development, property type, and city-center, the local property crime rate (larceny rate), and $\log$ of the sale price. Panel B then reports results from the two-stage binary response regressions of the probability of new bank financing on the instrumented broker variable, which is first estimated under a first-stage linear probability model. The dependent variable in the second stage regression is one if new bank financing is obtained and zero otherwise. Panel C reports results from the two-stage truncated regressions of the magnitude of new bank financing on instrumented brokerage activity. The dependent variable in the second stage regression is the fraction of the property's value financed by the loan. The data is truncated to only those observations where the dependent variable is positive. Panel D reports these regressions using the non-instrumented broker variable for comparison. Two sets of dependent variables are used: new mortgage financing from a bank (Newm) and new mortgage financing conditional on no seller financing being present $\left(\mathrm{Newm}^{\dagger}\right)$. Coefficient estimates are calculated via Klein and Spady's (1993) robust semiparametric binary response model and Powell's (1986) truncated model, with t-statistics reported in parentheses, where the time-series average of the coefficient estimates over the period January 1, 1992 to March 30, 1999 and their associated t-statistics are calculated in the style of Fama and MacBeth (1973). All regressions include state dummies, which are omitted from the table for brevity.

\begin{tabular}{|c|c|c|c|c|c|c|}
\hline \multirow[b]{3}{*}{ Dep. var. } & \multicolumn{6}{|c|}{ Panel A: Broker Instrumented Regression (Klein-Spady Binary Response) } \\
\hline & \multicolumn{4}{|c|}{ Population Personal } & \multicolumn{2}{|c|}{ Broker } \\
\hline & Radius & Crime & $\sigma_{\text {local }}$ & $\frac{\$ \text { National }}{\text { \$Brokered }}$ & \multicolumn{2}{|l|}{ Herfindahl } \\
\hline \multirow{2}{*}{$\begin{array}{l}\text { Broker Presence } \\
\text { (t-stat) }\end{array}$} & 0.037 & $-0.383^{* *}$ & $-0.113^{*}$ & $-1.493^{*}$ & \multirow{2}{*}{\multicolumn{2}{|c|}{$\begin{array}{c}-3.995^{* *} \\
(-2.80)\end{array}$}} \\
\hline & $(0.75)$ & $(-2.63)$ & $(-1.79)$ & $(-1.88)$ & & \\
\hline \multirow{3}{*}{$\begin{array}{r}\text { Regression: } \\
\text { Dep. var.: }\end{array}$} & \multirow{2}{*}{\multicolumn{2}{|c|}{$\begin{array}{c}\text { Panel B: } \\
\text { Klein-Spady Binary Response }\end{array}$}} & \multirow{2}{*}{\multicolumn{2}{|c|}{$\begin{array}{c}\text { Panel C: } \\
\text { Powell Truncated }\end{array}$}} & \multicolumn{2}{|c|}{ Panel D: } \\
\hline & & & & & Klein-Spady & Powell \\
\hline & Newm $>0$ & $\mathrm{Newm}^{\dagger}>0$ & Newm & Newm ${ }^{\dagger}$ & Newm $>0$ & Newm \\
\hline \multirow[t]{2}{*}{ Non-Corporate Buyer } & $0.086^{* *}$ & $0.223^{* *}$ & -0.006 & -0.006 & 0.122 & $-0.007^{* *}$ \\
\hline & $(4.17)$ & $(2.11)$ & $(-1.48)$ & $(-1.45)$ & (1.06) & $(-2.57)$ \\
\hline \multirow[t]{2}{*}{ SellDist } & -0.002 & 0.035 & 0.001 & $0.001^{*}$ & -0.006 & 0.000 \\
\hline & $(-0.93)$ & (1.59) & $(1.47)$ & $(1.80)$ & $(-1.63)$ & $(1.15)$ \\
\hline \multirow[t]{2}{*}{ BuyDist } & $-0.011^{* *}$ & 0.003 & 0.000 & 0.000 & $-0.086^{* *}$ & 0.000 \\
\hline & $(-3.13)$ & $(0.28)$ & $(0.41)$ & $(0.06)$ & $(-1.99)$ & $(1.21)$ \\
\hline \multirow[t]{2}{*}{ Dev. } & -0.030 & $-0.057^{* *}$ & 0.008 & 0.004 & 0.639 & $0.014^{* *}$ \\
\hline & $(-1.27)$ & $(-2.94)$ & $(0.91)$ & $(0.45)$ & $(1.54)$ & $(2.14)$ \\
\hline \multirow[t]{2}{*}{ Age } & $0.001^{* *}$ & 0.000 & 0.000 & 0.000 & $0.006^{*}$ & 0.000 \\
\hline & $(3.82)$ & $(-0.41)$ & $(-0.53)$ & (1.39) & $(1.82)$ & $(0.59)$ \\
\hline \multirow[t]{2}{*}{ Land } & $-1.263^{* *}$ & $-2.410^{* *}$ & -0.011 & -0.006 & $-6.124^{* *}$ & 0.005 \\
\hline & $(-7.51)$ & $(-2.36)$ & $(-0.55)$ & $(-0.26)$ & $(-2.26)$ & $(0.26)$ \\
\hline \multirow[t]{2}{*}{ Apt. } & $0.595^{* *}$ & $0.653^{* *}$ & $0.023^{* *}$ & $0.022^{* *}$ & $1.936^{* *}$ & $0.010^{*}$ \\
\hline & $(7.02)$ & $(2.73)$ & $(2.69)$ & $(2.94)$ & $(2.45)$ & $(1.82)$ \\
\hline \multirow[t]{2}{*}{ City-Center } & -0.010 & -0.030 & -0.001 & -0.002 & $-0.073^{* *}$ & -0.004 \\
\hline & $(-1.31)$ & $(-1.26)$ & $(-0.21)$ & $(-0.39)$ & $(-3.78)$ & $(-0.92)$ \\
\hline \multirow[t]{2}{*}{ Property Crime } & $-0.015^{* *}$ & 0.004 & 0.001 & 0.002 & $0.068^{*}$ & $0.003^{* *}$ \\
\hline & $(-2.03)$ & $(1.19)$ & $(1.03)$ & $(1.57)$ & $(1.84)$ & $(3.86)$ \\
\hline \multirow[t]{2}{*}{ Broker (Instr.) } & $1.362^{* *}$ & $3.909^{* *}$ & $-0.131^{*}$ & $-0.173^{* *}$ & & \\
\hline & $(4.69)$ & $(2.17)$ & $(-1.85)$ & $(-2.67)$ & & \\
\hline \multirow[t]{2}{*}{ Broker } & & & & & $1.383^{* *}$ & $-0.017^{* *}$ \\
\hline & & & & & $(2.35)$ & $(-6.20)$ \\
\hline \multirow[t]{2}{*}{$\log ($ Price $)$} & -1.000 & -1.000 & $-0.006^{* *}$ & $-0.005^{*}$ & -1.000 & $-0.006^{* *}$ \\
\hline & - & - & $(-2.10)$ & $(-1.83)$ & - & $(-4.32)$ \\
\hline
\end{tabular}

$\dagger$ All property sales that do not employ any form of seller financing.

${ }^{* *, *}$ significant at the $5 \%$ and $10 \%$ levels, respectively. 


\section{Broker-Bank Relationships and the Impact on Capital Structure}

The concentration of brokered deals among banks is reported using two concentration measures: 1) the Herfindahl index of each broker among banks and 2) the maximum share of a broker's deals devoted to a bank. These measures are also computed for a matched sample of non-brokered deals and their average differences along with t-statistics (in parentheses) are reported below. Also reported is the elasticity of the broker's share devoted to a particular bank with respect to the longevity of the relationship between the broker and the bank. This is simply a regression across brokers of the broker's share of deals sent to the bank (measured from 1997 to 1999) on the age of the earliest deal the broker did with that bank (measured prior to 1997). We repeat the regression using the bank's share of deals conducted by the broker as the dependent variable, estimated across banks. Also reported are results from the two-stage binary response regressions of the probability of new bank financing on brokerage activity and broker-bank concentration and longevity measures. Brokerage activity is first estimated using the instrumental variables from Table II under a first-stage linear probability model to account for the endogenous choice of brokers. The instrumented broker variable is then interacted with a dummy variable indicating whether the broker concentrates his deals among fewer banks than the population of deals (i.e., if the broker's bank Herfindahl index is greater than the matched sample) and is interacted with the broker's age in this market. The regressors in the second stage regression include the property, buyer, and seller characteristics from Table II, which are not reported for brevity. Coefficient estimates are calculated via Klein and Spady's (1993) robust semiparametric binary response model, with t-statistics reported in parentheses, where the time-series average of the coefficient estimates and their associated t-statistics are calculated in the style of Fama and MacBeth (1973). All regressions include state dummies, which are also omitted from the table for brevity.

\begin{tabular}{|c|c|c|c|}
\hline \multirow[b]{3}{*}{ BankHerf } & \multicolumn{3}{|c|}{ Bank Concentration Measures } \\
\hline & Brokered & Non-Brokered & $\begin{array}{l}\text { Difference } \\
\text { (t-stat) }\end{array}$ \\
\hline & 12.06 & 6.16 & $\begin{array}{l}5.89^{* *} \\
(3.47)\end{array}$ \\
\hline \multirow{6}{*}{$\begin{array}{r}\text { Longevity of Relationship in years } \\
\text { (t-stat) }\end{array}$} & 21.89 & 13.60 & $\begin{array}{l}8.29^{* *} \\
(4.08)\end{array}$ \\
\hline & \multicolumn{3}{|c|}{ Broker-Bank Longevity Measures } \\
\hline & Dependent Variable: & $\begin{array}{l}\text { Share of Broker's Deals } \\
\text { Directed to the Bank }\end{array}$ & $\begin{array}{c}\text { Share of the Bank's Deals } \\
\text { Done by the Broker }\end{array}$ \\
\hline & & $0.0036^{* *}$ & $0.0568^{* *}$ \\
\hline & & $(3.15)$ & $(14.98)$ \\
\hline & \multicolumn{3}{|c|}{$\begin{array}{c}\text { Impact on Capital Structure } \\
\text { Klein-Spady Binary Response Model } \\
\text { (Fama-MacBeth Regressions) }\end{array}$} \\
\hline Dep. var.: & Newm & Newm & Newm \\
\hline Broker (Instr.) & $\begin{array}{c}8.992^{* *} \\
(2.01)\end{array}$ & $\begin{array}{c}0.856^{* *} \\
(2.37)\end{array}$ & $\begin{array}{l}0.224 \\
(1.10)\end{array}$ \\
\hline Broker(Instr.) $\times$ Conc. $($ Herf $)$ & $\begin{array}{c}0.809^{* *} \\
(2.94)\end{array}$ & & \\
\hline Broker $($ Instr. $) \times$ Conc. $($ Share $)$ & & $\begin{array}{c}0.327^{* *} \\
(3.84)\end{array}$ & \\
\hline Broker(Instr.) $\times$ Broker Longevity & & & $\begin{array}{c}0.0365^{* *} \\
(5.62)\end{array}$ \\
\hline
\end{tabular}

**,* significant at the $5 \%$ and $10 \%$ levels, respectively. 


\section{Broker Herding, Loyalty, and the Impact on Capital Structure}

Measures of broker-bank loyalty and herding are reported. The loyalty of brokered deals among banks is assessed via the elasticity of the change in a broker's share of business with the bank with respect to the change in the bank's share of the commercial market. This is simply a regression of the change in the broker's share devoted to a particular bank on the change in the bank's share of the market. The change in the share of broker business devoted to each bank is measured both by number of transactions (Loyalty (Num)) and by dollar volume (Loyalty (\$)). Also reported is a measure of herding among brokers in certain banks. This measure is the absolute value of the difference between the fraction of a bank's deals that are brokered and the fraction of all bank deals that are brokered, minus the expected value of this absolute difference, which is estimated using a simulation under a binomial distribution. The average loyalty and herding measures are reported across brokers and banks, respectively, along with t-statistics in parentheses. These measures are also reported separately for brokers with less than and greater than $\$ 10$ million in transaction volume, and for banks with less than and greater than 10 deals. Also reported are results from the two-stage binary response regressions of the probability of new bank financing on brokerage activity and broker-bank loyalty. Brokerage activity is first estimated using the instrumental variables from Table II under a first-stage linear probability model to account for the endogenous choice of brokers. The instrumented broker variable is then interacted with a dummy variable indicating whether the broker is loyal to his banks (i.e., if the broker's elasticity measure is less than 1). We also report results for the interaction between broker presence and non-loyalty (i.e., broker elasticity greater than 1). The regressors in the second stage regression include the property, buyer, and seller characteristics from Table II, which are not reported for brevity. Coefficient estimates are calculated via Klein and Spady's (1993) robust semiparametric binary response model, with t-statistics reported in parentheses, where the time-series average of the coefficient estimates and their associated t-statistics are calculated in the style of Fama and MacBeth (1973). All regressions include state dummies, which are also omitted from the table for brevity.

\begin{tabular}{|c|c|c|c|}
\hline \multirow{4}{*}{$\begin{array}{r}\text { Broker Herding into Banks } \\
\text { Different from } 0 \text { (t-stat) }\end{array}$} & \multicolumn{3}{|c|}{ "Bank Herding Measures } \\
\hline & All Banks & Small Banks ( $<10$ Deals $)$ & Large Banks ( $\geq 10$ Deals $)$ \\
\hline & $0.0222^{* *}$ & 0.0064 & $0.0584^{* *}$ \\
\hline & $(6.08)$ & $(1.32)$ & $(14.89)$ \\
\hline \multirow{6}{*}{$\begin{array}{c}\text { Elasticity of Broker-Bank Business } \\
\text { Different from } 1 \text { (t-stat) }\end{array}$} & \multicolumn{3}{|c|}{ Broker-Bank Loyalty Measures } \\
\hline & All Brokers & Small Deals $(<\$ 10 m)$ & Large Deals $(\geq \$ 10 m)$ \\
\hline & 1.08 & $0.80^{* *}$ & $1.38^{*}$ \\
\hline & $(0.77)$ & $(-2.56)$ & $(1.78)$ \\
\hline & \multicolumn{3}{|c|}{$\begin{array}{c}\text { Impact of Loyalty on Capital Structure } \\
\text { Klein-Spady Binary Response Model } \\
\text { (Fama-MacBeth Regressions) }\end{array}$} \\
\hline & Newm & Newm & Newm \\
\hline Broker (Instr.) & $\begin{array}{c}0.343^{* *} \\
(2.19)\end{array}$ & $\begin{array}{c}1.108^{* *} \\
(4.71)\end{array}$ & $\begin{array}{l}-0.528 \\
(-0.49)\end{array}$ \\
\hline Broker(Instr.) $\times$ Loyalty $($ Num $)$ & $\begin{array}{l}0.052^{* *} \\
(5.04)\end{array}$ & $\begin{array}{c}0.122^{* *} \\
(2.87)\end{array}$ & \\
\hline Broker(Instr.) $\times$ Disloyalty (Num) & & $\begin{array}{c}-0.085^{* *} \\
(-2.88)\end{array}$ & \\
\hline Broker(Instr.) $\times$ Loyalty $(\$)$ & & & $0.047^{* *}$ \\
\hline Broker(Instr.) $\times$ Disloyalty $(\$)$ & & & $\begin{array}{c}(4.47) \\
-0.157^{* *} \\
(-2.69)\end{array}$ \\
\hline
\end{tabular}

$* *, *$ significant at the $5 \%$ and $10 \%$ levels, respectively. 
Table V:

\section{Do Brokers Influence Other Forms of Financing?}

Results from the two-stage binary response and truncated regressions of the probability and magnitude of various forms of financing on instrumented brokerage activity are reported below over the January 1, 1992 to March 30, 1999 time period. Brokerage activity is first estimated using the instrumental variables from Table II under a first-stage linear probability model to account for the endogenous choice of brokers. Three sets of dependent variables are used: vendor-to-buyer financing (VTB), VTB financing conditional on no bank financing being present $\left(\mathrm{VTB}^{\dagger}\right)$, and the assumption of an existing mortgage (Assm). Panel A reports coefficient estimates for the probability of each form of financing, estimated under Klein and Spady's (1993) robust semiparametric binary response model. Panel B reports coefficient estimates for the magnitude of each form of financing (as a fraction of the sale price), estimated under Powell's (1986) truncated regression model. In addition to the instrumented broker variable, the regressors include the buyer, seller, and property characteristics of Table II. T-statistics are reported in parentheses, where the timeseries average of the coefficient estimates and their associated t-statistics are calculated in the style of Fama and MacBeth (1973). All regressions include state dummies, which are omitted from the table for brevity.

\begin{tabular}{|c|c|c|c|c|c|}
\hline \multirow[b]{2}{*}{ Dep. var.: } & \multicolumn{3}{|c|}{$\begin{array}{c}\text { Panel A: Binary Response } \\
\text { Probability of }\end{array}$} & \multicolumn{2}{|c|}{$\begin{array}{l}\text { Panel B: Truncated } \\
\text { Magnitude of }\end{array}$} \\
\hline & VTB & $\mathrm{VTB}^{\dagger}$ & Assm & VTB & $\mathrm{VTB}^{\dagger}$ \\
\hline Non-Corporate Buyer & $\begin{array}{c}0.793^{*} \\
(1.92)\end{array}$ & $\begin{array}{c}3.298^{* *} \\
(2.84)\end{array}$ & $\begin{array}{l}-0.128 \\
(-1.36)\end{array}$ & $\begin{array}{l}-0.172 \\
(-1.37)\end{array}$ & $\begin{array}{l}-0.009 \\
(-0.50)\end{array}$ \\
\hline SellDist & $\begin{array}{c}-0.004^{* *} \\
(-2.28)\end{array}$ & $\begin{array}{l}0.006 \\
(1.14)\end{array}$ & $\begin{array}{l}-0.010 \\
(-1.35)\end{array}$ & $\begin{array}{l}-0.024 \\
(-1.50)\end{array}$ & $\begin{array}{c}0.001^{* *} \\
(2.34)\end{array}$ \\
\hline BuyDist & $\begin{array}{l}0.027 \\
(1.40)\end{array}$ & $\begin{array}{l}-0.018 \\
(-1.06)\end{array}$ & $\begin{array}{l}0.005^{*} \\
(1.76)\end{array}$ & $\begin{array}{l}0.029 \\
(1.35)\end{array}$ & $\begin{array}{c}-0.003^{* *} \\
(-2.93)\end{array}$ \\
\hline Dev. & $\begin{array}{l}0.067 \\
(1.24)\end{array}$ & $\begin{array}{l}0.020 \\
(0.09)\end{array}$ & $\begin{array}{l}-0.323^{*} \\
(-1.84)\end{array}$ & $\begin{array}{l}0.396 \\
(1.58)\end{array}$ & $\begin{array}{c}-0.074^{* *} \\
(-4.00)\end{array}$ \\
\hline Age & $\begin{array}{c}0.014^{* *} \\
(2.37)\end{array}$ & $\begin{array}{c}0.055^{* *} \\
(1.97)\end{array}$ & $\begin{array}{c}0.007^{* *} \\
(2.65)\end{array}$ & $\begin{array}{l}0.000 \\
(0.68)\end{array}$ & $\begin{array}{c}0.001^{* *} \\
(2.08)\end{array}$ \\
\hline Land & $\begin{array}{l}0.009 \\
(0.02)\end{array}$ & $\begin{array}{c}-3.679^{* *} \\
(-2.70)\end{array}$ & $\begin{array}{c}2.148^{*} \\
(1.76)\end{array}$ & $\begin{array}{c}-0.042^{*} \\
(-1.91)\end{array}$ & $\begin{array}{c}-0.100^{* *} \\
(-5.18)\end{array}$ \\
\hline Apt. & $\begin{array}{c}0.242^{* *} \\
(2.15)\end{array}$ & $\begin{array}{l}-0.038 \\
(-0.43)\end{array}$ & $\begin{array}{c}2.357^{* *} \\
(2.45)\end{array}$ & $\begin{array}{c}-0.809^{* *} \\
(-2.79)\end{array}$ & $\begin{array}{c}0.051^{* *} \\
(4.90)\end{array}$ \\
\hline City-Center & $\begin{array}{l}0.014^{*} \\
(1.84)\end{array}$ & $\begin{array}{c}-0.429^{* *} \\
(-2.02)\end{array}$ & $\begin{array}{l}-0.065 \\
(-1.00)\end{array}$ & $\begin{array}{c}0.132 \\
(1.51)\end{array}$ & $\begin{array}{c}-0.012^{* *} \\
(-2.17)\end{array}$ \\
\hline Property Crime & $\begin{array}{c}0.058^{* *} \\
(1.96)\end{array}$ & $\begin{array}{c}-0.084^{* *} \\
(-3.16)\end{array}$ & $\begin{array}{l}0.009 \\
(1.35)\end{array}$ & $\begin{array}{c}-0.062^{*} \\
(-1.71)\end{array}$ & $\begin{array}{c}0.014^{* *} \\
(3.29)\end{array}$ \\
\hline Broker as Principal & $\begin{array}{c}0.205^{* *} \\
(4.05)\end{array}$ & $\begin{array}{c}0.169 \\
(1.11)\end{array}$ & $\begin{array}{c}1.427^{* *} \\
(2.45)\end{array}$ & $\begin{array}{l}-0.026 \\
(-1.42)\end{array}$ & $\begin{array}{c}-0.027^{* *} \\
(-2.41)\end{array}$ \\
\hline Broker(Instr.) & $\begin{array}{c}8.232 \\
(1.49)\end{array}$ & $\begin{array}{c}4.641^{* *} \\
(2.29)\end{array}$ & $\begin{array}{c}14.392^{* *} \\
(2.30)\end{array}$ & $\begin{array}{c}-1.195^{* *} \\
(-1.97)\end{array}$ & $\begin{array}{c}-0.464^{* *} \\
(-6.51)\end{array}$ \\
\hline $\log$ (Price) & $\begin{array}{c}-1.000 \\
- \\
\end{array}$ & $\begin{array}{c}-1.000 \\
-\end{array}$ & $\begin{array}{c}-1.000 \\
-\end{array}$ & $\begin{array}{c}-0.065^{* *} \\
(-5.85)\end{array}$ & $\begin{array}{c}-0.014^{* *} \\
(-3.54)\end{array}$ \\
\hline
\end{tabular}

$\dagger$ All property sales that do not employ any form of bank financing.

${ }^{* * * *}$ significant at the $5 \%$ and $10 \%$ levels, respectively. 


\section{The Role of Broker Selection and the Influence on Sale Prices}

Panel A reports results from the two-stage least squares regressions of the probability of vendor financing and capitalization rates on instrumented brokerage activity over the January 1, 1992 to March 30, 1999 time period. Brokerage activity is first estimated using the instrumental variables from Table II under a first-stage linear probability model to account for the endogenous choice of brokers. The dependent variables in the second stage regression are the presence of vendor financing (estimated under the Klein and Spady (1993) binary response model) and the capitalization rate of the property (Cap. Rate), defined as net operating income on the property divided by the sale price (estimated via ordinary least squares). Panel B repeats these regressions using the non-instrumented broker presence variable to gauge the impact of broker selection on vendor financing and price. The buyer, seller, and property characteristics from Table II are included as additional regressors. The time-series average of the coefficient estimates and their associated t-statistics are calculated in the style of Fama and MacBeth (1973). All regressions include state dummies, which are omitted from the table for brevity.

\begin{tabular}{|c|c|c|c|c|}
\hline \multirow{3}{*}{$\begin{array}{r}\text { Regression Model: } \\
\text { Dep. var.: }\end{array}$} & \multicolumn{2}{|c|}{ Panel A: Instrumented } & \multicolumn{2}{|c|}{ Panel B: Non-Instrumented } \\
\hline & OLS & Klein-Spady & OLS & Klein-Spady \\
\hline & Cap. Rate & VTB & Cap. Rate & VTB \\
\hline \multirow[t]{2}{*}{ Non-Corporate Buyer } & $-0.346^{* *}$ & $0.793^{*}$ & $-0.348^{* *}$ & 0.869 \\
\hline & $(-2.35)$ & $(1.92)$ & $(-10.34)$ & $(1.63)$ \\
\hline \multirow[t]{2}{*}{ SellDist } & 0.011 & $-0.004^{* *}$ & $0.009^{* *}$ & $-0.001^{*}$ \\
\hline & $(1.53)$ & $(-2.28)$ & $(2.17)$ & $(-1.80)$ \\
\hline \multirow[t]{2}{*}{ BuyDist } & -0.006 & 0.027 & $-0.007^{* *}$ & -0.016 \\
\hline & $(-0.87)$ & $(1.40)$ & $(-2.46)$ & $(-1.40)$ \\
\hline \multirow[t]{2}{*}{ Dev. } & -0.225 & 0.067 & $-0.278^{* *}$ & $-0.020^{*}$ \\
\hline & $(-1.24)$ & $(1.24)$ & $(-2.42)$ & $(-1.89)$ \\
\hline \multirow[t]{2}{*}{ Age } & $0.002^{* *}$ & $0.014^{* *}$ & $0.002^{* *}$ & $0.015^{*}$ \\
\hline & $(2.25)$ & $(2.37)$ & $(1.98)$ & $(1.86)$ \\
\hline \multirow[t]{2}{*}{ Land } & -0.124 & 0.009 & -0.212 & -0.760 \\
\hline & $(-0.42)$ & $(0.02)$ & $(-1.46)$ & $(-1.31)$ \\
\hline \multirow[t]{2}{*}{ Apt. } & $-0.299^{*}$ & $0.242^{* *}$ & $-0.246^{* *}$ & $-0.121^{* *}$ \\
\hline & $(-1.66)$ & $(2.15)$ & $(-3.30)$ & $(-2.47)$ \\
\hline \multirow[t]{2}{*}{ City-Center } & 0.029 & $0.014^{*}$ & -0.018 & -0.004 \\
\hline & $(0.46)$ & $(1.84)$ & $(-0.29)$ & $(-0.55)$ \\
\hline \multirow[t]{2}{*}{ Property Crime } & $0.167^{* *}$ & $0.058^{* *}$ & $0.198 * *$ & 0.016 \\
\hline & $(4.17)$ & $(1.96)$ & $(4.55)$ & $(1.22)$ \\
\hline \multirow[t]{2}{*}{ Broker as Principal } & $-0.293^{* *}$ & $0.205^{* *}$ & $-0.199 * *$ & $0.116^{* *}$ \\
\hline & $(-2.93)$ & $(4.05)$ & $(-2.28)$ & $(3.71)$ \\
\hline \multirow[t]{2}{*}{ Broker (Instr.) } & 0.005 & 8.232 & & \\
\hline & $(0.26)$ & $(1.49)$ & & \\
\hline \multirow[t]{2}{*}{ Broker } & & & $0.421^{* *}$ & $-0.256^{* *}$ \\
\hline & & & $(6.05)$ & $(-5.36)$ \\
\hline \multirow[t]{2}{*}{$\log ($ Price $)$} & -0.144 & -1.000 & $-0.089^{* *}$ & -1.000 \\
\hline & $(-1.58)$ & - & $(-2.03)$ & - \\
\hline
\end{tabular}

\footnotetext{
**,* significant at the $5 \%$ and $10 \%$ levels, respectively.
} 


\section{Summary of Theoretical Predictions and Results}

\begin{tabular}{|c|c|c|}
\hline Prediction & Predicted By Which Theories? & Verified? \\
\hline $\begin{array}{l}\text { 1. Brokered deals are more likely to receive } \\
\text { new bank financing. }\end{array}$ & All & Yes \\
\hline $\begin{array}{l}\text { 2. Brokers will concentrate their deals among a small } \\
\text { number of banks. }\end{array}$ & Cooperation & Yes \\
\hline $\begin{array}{l}\text { 3. Brokers with strong bank relationships will have a larger } \\
\text { effect on the granting of bank loans than the average broker. }\end{array}$ & Cooperation & Yes \\
\hline $\begin{array}{l}\text { 4. Brokers will direct a greater proportion of their clients } \\
\text { to banks with whom they have longer relationships. }\end{array}$ & Cooperation & Yes \\
\hline $\begin{array}{l}\text { 5. Banks will offer more loans to the clients of brokers with } \\
\text { whom they have longer relationships. }\end{array}$ & Cooperation & Yes \\
\hline $\begin{array}{l}\text { 6. Brokers who have participated in the market for a longer } \\
\text { period of time will have a larger effect on the granting of bank } \\
\text { loans than the average broker. }\end{array}$ & Cooperation & Yes \\
\hline $\begin{array}{l}\text { 7. When the buyer does not receive bank financing, the size } \\
\text { of VTB loans will be smaller in brokered deals than in } \\
\text { non-brokered deals. }\end{array}$ & Cooperation & Yes \\
\hline $\begin{array}{l}\text { 8. Brokered deals are more likely to receive } \\
\text { assumed mortgage financing. }\end{array}$ & Cooperation & Yes \\
\hline $\begin{array}{l}\text { A1.i. The elasticity of a bank's brokerage business } \\
\text { with respect to its total loan business will be } \\
\text { greater than one. } \\
\text { A1.ii. The elasticity of a bank's brokerage business } \\
\text { with respect to its total loan business will be } \\
\text { less than one. }\end{array}$ & Cooperation & large deals \\
\hline $\begin{array}{l}\text { A2.i. Disloyal brokers will most improve their clients' } \\
\text { probability of receiving a bank loan. } \\
\text { A2.ii. Loyal brokers will most improve their clients' } \\
\text { probability of receiving a bank loan. }\end{array}$ & Cooperation & $\begin{array}{l}\text { No } \\
\text { Yes }\end{array}$ \\
\hline $\begin{array}{l}\text { A3. Brokers from different firms will herd in directing } \\
\text { their clients to the same banks }\end{array}$ & Advisory & weak \\
\hline B1. The size of bank loans will be greater for brokered deals & Certification & No \\
\hline B2. Brokered properties will receive higher average prices & Certification & No \\
\hline C1. Brokered deals will exhibit less VTB financing & Selection & Yes* \\
\hline C2. Brokered properties will receive lower average prices & Selection & Yes* \\
\hline
\end{tabular}

${ }^{*}$ Using the non-instrumented broker variables. Employing the instrumented broker variables, these results do not hold, suggesting our instruments successfully capture the endogenous choice of brokers. 